УДК 553.2:549.283 (571.52)

\title{
ЗОЛОТО-СУЛЬФИДНО-КВАРЦЕВОЕ РУДОПРОЯВЛЕНИЕ ХААК-САИР (ЗАПАДНАЯ ТУВА): ВОЗРАСТ, РТ-ПАРАМЕТРЫ, СОСТАВ ФЛЮИДОВ, ИЗОТОПИЯ S, О И С
}

\author{
Кужугет Ренат Васильевич1, \\ rkuzhuget@mail.ru
}

\author{
Анкушева Наталья Николаевна², \\ ankusheva@mail.ru
}

Кадыр-оол Чаяна Олекоевна',
kadyrool91@mail.ru

\author{
Редина Анна Андреевна ${ }^{3}$, \\ anna-red@outlook.com
}

\author{
Прокопьев Илья Романовичз, \\ prokopev_ilya@mail.ru
}

\section{Пономарчук Антон Викторович³, antponomar@gmail.com}

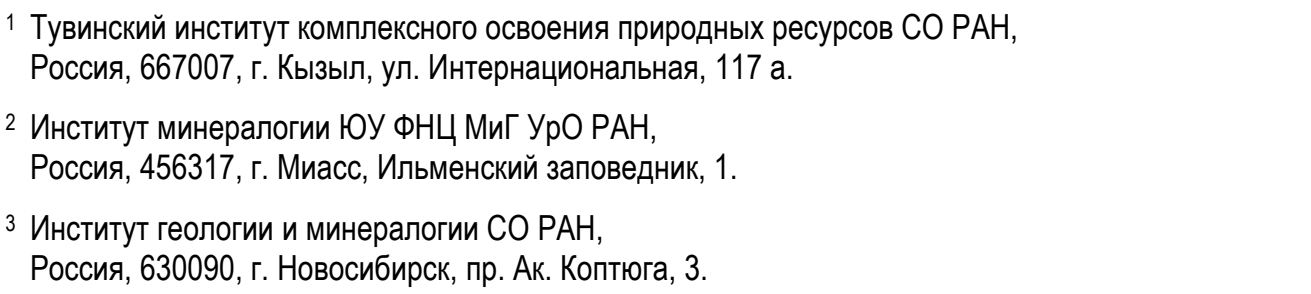

Актуальность исследования обусловлена необходимостью определения возраста и условий образования золото-квариевого рудопроявления Хаак-Саир в лиственитах, характеризующегося своеобразным минеральным составом руд, выраженным $в$ наличии ртутистого золота, селенидов (фришессерита, науманнита, тиманнита, клаусталита) и теллуридов (гессита, теллуровисмутита и колорадоита).

Цель: определение возраста, условий образования, геохимических особенностей рудоносного фрлюида и его источников, золото-квариевого рудопроявления Хаак-Саир в Западной Туве.

Методы. Оптические исследования руд проведены на микроскоnах Olympus BX41 и ПОЛАМ П-213М. Состав минералов определен с помощью сканирующего электронного микроскоnа MIRA 3 LMU с ЭДC Oxford Instruments Nanoanalysis Ltd. Teмnepamyры, солевой состав, концентрации солей и давление при минералообразовании получены по индивидуальным фрлюидным включениям с использованием термокамеры Linkam TMS-600 и оптического микроскопа Olympus BX 51; газовый состав фрлюидных включений определен на рамановском спектрометре Ramanor U-1000 с детектором Horiba DU420E-OE-323, лазер Millennia Pro (Spectra-Physics); валовый газовый состав фрлюида диагностирован на газовом хроматографре Agilent 6890, содержания анионов в вытяжке проанализированы на жидкостном хроматографе ЦВЕТ-3000, катионы и микроэлементы - методом ICP MS

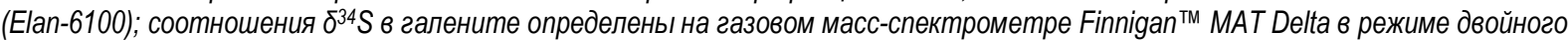
напуска (аналитики В.Н. Реутский, М.Н. Колбасова, ИГМ СО РАН); соотношения стабильных изотопов $\delta^{18} \mathrm{C}$ и $\delta^{18} \mathrm{O}$ в кварце и карбонатах определены на масс-спектрометрах Stable Isotope Ratio Mass Spectrometer Finnigan ${ }^{\mathrm{TM}}$ MAT 253 с пробоотборником Finnigan GasBench II и стандартами IAEA: NBS-18 и NBS-19 (аналитик A.H. Пыряев, ИГМ CO PAH) и Isoprime c AQS (Akita Quartz Standard, аналитики Х. Каварая, О. Мацубая, Университет г. Акита), соответственно; ${ }^{40} \mathrm{Ar}{ }^{39} \mathrm{Ar}$ датирование проведено методом ступенчатого прогрева.

Результаты. Установленный ${ }^{40} \mathrm{Ar}{ }^{39} \mathrm{Ar}$ методом возраст синрудных лиственитов рудопроявления составляет $379,4 \pm 4,4$ млн лет, что соответствует позднему девону. Термометрическими исследованиями установлено, что вмещающие лиственить рудопроявления образовались при участии водного Na-K-хлоридного флюида с соленостью 3,4-6,5 мас. \% NaCl-экв. и температурами не менее $325-200{ }^{\circ} \mathrm{C}$. Золото-сульфидно-квариевые жилы отлагались при P 0,5-0,75 кбар ( 1,5-2,3 км) из углекислотно-водно-хлоридного ( $\mathrm{Na}-\mathrm{K} \pm \mathrm{Fe}$ ) фрлюида, содержащего $\mathrm{CH}_{4}$ с кониентрациями солей 4,5-37,4 мас. \% NaCl-экв. при снижении температур от 320 до $120{ }^{\circ} \mathrm{C}$ (I рудная стадия - 310-200 ${ }^{\circ} \mathrm{C}$, II рудная стадия - 320-120 ${ }^{\circ} \mathrm{C}$ ) и вариациях $f \mathrm{O}_{2}, f S_{2}, f \mathrm{Se}_{2} u$ $f \mathrm{Te}_{2}$, которые обусловили разнообразие минеральных форм $\mathrm{Au}$, $\mathrm{Ag}$ u Hg. Величины $\delta^{34} \mathrm{~S}$ галенита изменяются от $-0,6$ до $0,4 \%$, а вычисленные значения $\delta^{34} \mathrm{~S}_{22}$ фрлюида I рудной стадии находятся в интервале $+1,5 \ldots+2,1 \%$ ( $\left.T=280-210{ }^{\circ} \mathrm{C}\right)$, II рудной стадии - +1,6...+2,6 \% ( $\left.T=290-190{ }^{\circ} \mathrm{C}\right)$, что свидетельствует о магматическом происхождении серы. Значения $\delta^{18} \mathrm{O}$ в кварие рудных жил изменяются от 17,0 до 17,4\%, доломите - +17,4...+17,8\%, кальците - +16,5\%, рассчитанные значения $\delta^{18} \mathrm{OH}_{25}$ фрлюида I рудной стадии находятся в интервале $+8,1 \ldots+5,7 \%$ ( $\left.T=250-210{ }^{\circ} \mathrm{C}\right)$, , позволили предположить, что на ранних стадиях рудообразующего процесса фрюид имел магматическое происхождение, а на поздних смешивался с метеорными водами. Величины $\delta^{13} \mathrm{C}$ в доломите I рудной стадии варьируют от $-0,4$ до -0,7 \%; в кальиите II рудной стадии - -0,3\%, а рассчитанные значения $\delta^{13} \mathrm{C}$ во фолюиде находятся в интервале $-1,2 \ldots+0,1 \%$ ( $\left.T=250-210{ }^{\circ} \mathrm{C}\right)$ и $-3,3 . .+0,5 \%$ ( $\left(T=230-120{ }^{\circ} \mathrm{C}\right)$, соответственно. Это предполагает поступление углерода из гранитоидных магм и/или заимствование его из вмещающих пород. Состав фрлюида трансформировался от ранних стадий к поздним от углекислотноводно-хлоридного до водно-хлоридного с уменьшением концентраций хлоридов щелочных и щелочноземельных металлов (от 37,4 до 4 мас. \% NaCl-экв.).

Ключевые слова:

Самородное золото, фрлюидные включения, квари, возраст, стабильные изотопы, месторождения золота, Тува. 


\section{Введение}

Золото-кварцевое рудопроявление Хаак-Саир Алдан-Маадырского рудного узла (АМРУ) Западной Тувы считается одним из перспективных объектов на коренное Au в Республике Тыва. АМРУ приурочен к области развития $\mathrm{V}-\mathrm{C}_{1}$ океанических комплексов и $\mathrm{S}-\mathrm{O}$ пород коллизионного прогиба. Золотое оруденение парагенетически связано с интрузивными породами баянкольского комплекса $\left(\mathrm{D}_{3} b n\right)$ и сопряжено с процессами березитизации и лиственитизации рудовмещающих пород [1], а также контролируется оперяющими разломами субширотного простирания Саяно-Тувинского глубинного разлома.

Рудопроявление Хаак-Саир было открыто в 1952 г. Дальней экспедицией ВСЕГЕИ под руководством Г.М. Владимирского. В 1954-1955 и 1974-76 гг. оно было опробовано несколькими геологическими партиями в процессе геолого-съемочных и тематических работ, и были составлены детальные карты участков и рудного поля Сарыгдаш (Хаак-Саир) масштабов $1: 200$ и 1:10000, соответственно [2].

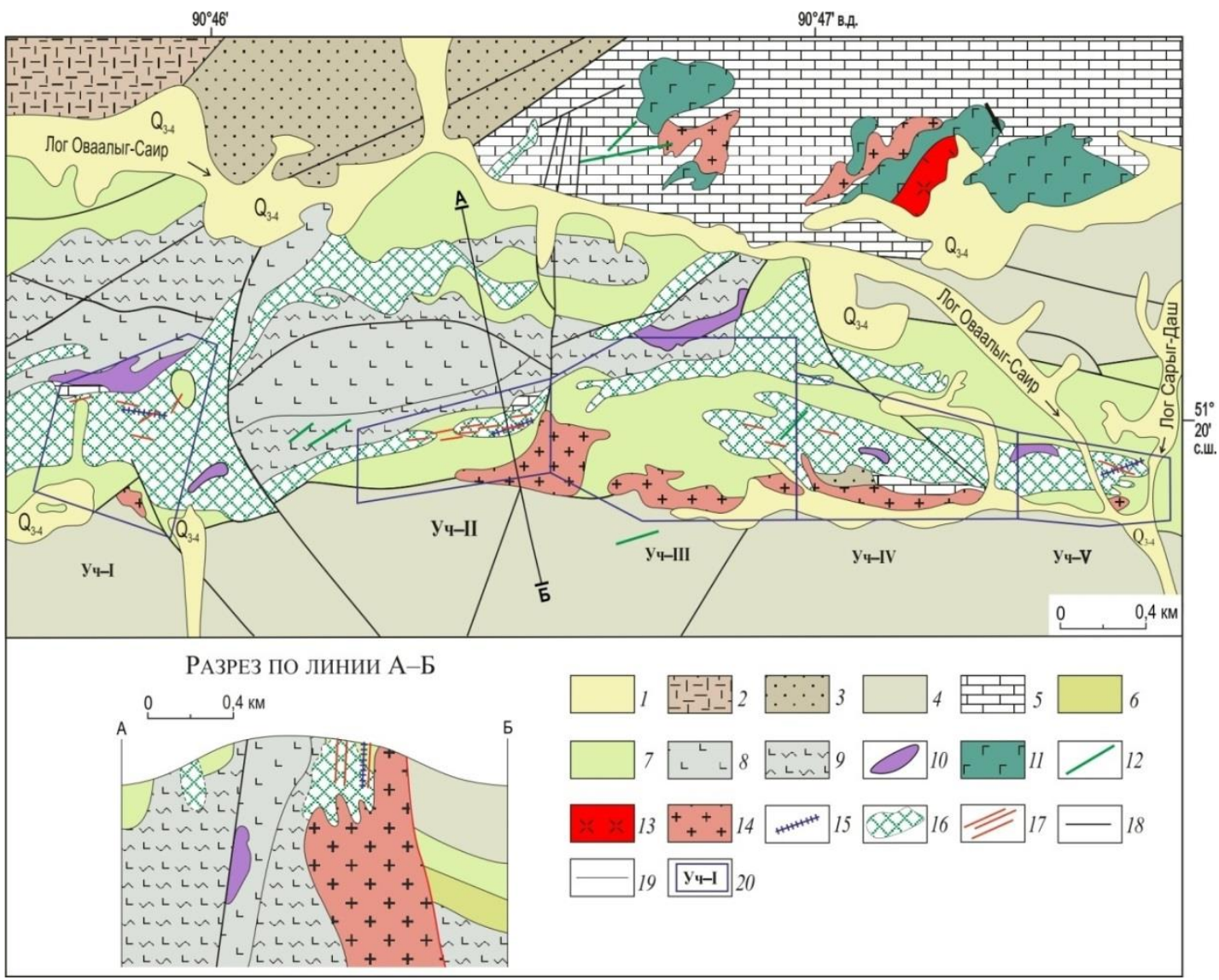

Рис. 1. Схема геологического строения рудопроявления Хаак-Саир (по данным [2] с изменениями): 1 - делювиальные и пролювиальные отложения $\left(Q_{3-4}\right) ; 2$ - дацит-риолитовые порфиры кендейской свиты $\left(D_{1} k n\right) ; 3$ - песчаники и алевролиты хондергейской свиты $\left(D_{I} h n\right) ; 4$ - серицито-глинистые сланцы и алевролиты чергакской свить $\left(S_{I} \check{c} r\right) ; 5$ - известняки чергакской свиты $\left(S_{l} \check{c} r\right) ; 6$ - алевролиты, гравелиты и песчаники адырташской свиты $\left(\mathrm{O}_{3} \mathrm{ad}\right)$; 7 - конгломераты с линзами песчаников и алевролитов адырташской свиты $\left(\mathrm{O}_{3} a d\right)$; 8 - спилиты алдынбулакской (чингинской) свиты (V-C $\left.C_{l} a t\right) ; 9$ - рассланцованные спилиты алдынбулакской свиты $\left(V-C_{l} a t\right)$; 10 - серпентиниты, перидотиты, пироксениты и габброиды акдовракского офиолитового комплекса ( $\left.\sigma \mathrm{V}-C_{1} a k\right) ; 11-14$ - баянкольский интрузивный комплекс (D $\left.{ }_{3} b n\right): 11$ - габброиды III фазы; 12 - дайки диоритов III фазы; 13 - интрузии риолит-порфиров II фазы; 14 - интрузии гранодиорит-, тоналит-порфиров I фазы; 15 - квари-турмалиновые метасоматиты; 16 - листвениты; 17 - рудные жиль;; 18 - разрывные нарушения; 19 - границы геологические; 20 - контуры участков рудопроявления Хаак-Саир

Fig. 1. Geological scheme of Khaak-Sair ore occurrence (after [2], modified): 1 - deluvial-proluvial sediments $\left(Q_{3-4}\right)$; 2 - effusive rocks, dacite and rhyolite porphyry of the Kendei Formation $\left(D_{l} k n\right) ; 3$ - siltstones and sandstones of the Khodergei Formation $\left(D_{l} h n\right) ; 4$ - sericite-clay shales of the Chergak Formation $\left(S_{1} \check{c} r\right) ; 5$-limestones and greenishgray siltstone lenses of the Chergak Formation $\left(S_{I} \check{c} r\right) ; 6$ - siltstones, gravelites and sandstones of the Adyrtash Formation $\left(\mathrm{O}_{3} \mathrm{ad}\right) ; 7$ - shale medium pebble conglomerates with lenses of siltstones and sandstones of the Adyrtash Formation $\left(\mathrm{O}_{3} \mathrm{ad}\right) ; 8$ - spilites of the Aldynbulak Formation $\left(\mathrm{V}-\mathrm{C}_{1}\right.$ at); 9 - shales, and shale spilites of the Aldynbulak Formation $\left(V-C_{1} a t\right) ; 10$ - serpentinites, peridotites, pyroxenites, and gabbroids of the Akdovrak ophiolite complex $\left(\sigma V-C_{1} a k\right) ; 11-14$ - intrusive rocks of the Bayan-Kol Complex $\left(D_{3} b n\right): 11$ - gabbroids of phase III; 12 - microdiorite dykes of phase III; 13 - rhyolite porphyry of phase II; 14 - granodiorite- and tonalite-porphyry, and graniteporphyry of phase I; 15 - quartz-tourmaline metasomatites; 16 - listwanites; 17 - ore veins; 18 - faults; 19 - geologic boundaries; 20 - Khaak-Sair ore occurrence and the outlines 
В 2009-2011 гг. ОАО «Красноярскгеолсъёмка» провело на АМРУ государственные ревизионнопоисковые работы на рудное Аu. В ходе этих работ в центральной части рудопроявления Хаак-Саир были выявлены жильно-прожилковые зоны протяженностью от 450 до 1200 м и мощностью 2-18 м и ресурсы $\mathrm{Au}$ категории $\mathrm{P}_{2}$ оценены в количестве 18 т [3].

Авторы данной статьи с 2008 г. проводили тематические исследования на объектах АМРУ по изучению их минералого-геохимических особенностей руд, по результатам которых рудопроявления были отнесены к малосульфидной золото-кварцевой вулканогенно-плутоногенной формации $[1,4]$, т. е. переходному типу от вулканогенных к плутоногенным гидротермальным месторождениям Аu.

В 2017-2019 гг. АО «Сибирское ПГО» провело государственные поисковые работы на рудное $\mathrm{Au}$ на площади АМРУ, включающие поисковые маршруты, литохимическое опробование по вторичным ореолам рассеяния, площадные геофизические работы, горные буровые и опробовательские работы. В ходе этих работ авторами статьи были отобраны образцы из горных выработок, использованные для изотопногеохронологических, изотопно-геохимических и термобарогеохимических исследований, что позволило получить новые данные о возрасте оруденения, геохимических особенностях флюидов и изотопном составе $\mathrm{S}, \mathrm{O}$ и С флюида.

\section{Геолого-минералогическая}

характеристика рудопроявления

Детальная геолого-минералогическая характеристика рудопроявления Хаак-Саир приведена в работе [4]. Здесь подчеркнём, что оруденение приурочено к горст-антиклинальной структуре субширотного простирания длиной 9 км и шириной 1-1,5 км. Крылья структуры осложнены субширотными тектоническими нарушениями: на севере - Аржанским разломом, на юге - Рудным разломом. Ядро структуры сложено $\mathrm{V}-\mathrm{E}_{1}$ вулканогенно-осадочными породами, крылья $\mathrm{O}_{3}-\mathrm{S}_{1}$ терригенно-осадочными отложениями (рис. 1). Рудный разлом сбросового типа, контролирующий оруденение, «залечен» тоналит-порфирами I фазы баянкольского комплекса $\left(\mathrm{D}_{3} b n\right)$, парагенетически связанными с оруденением. Разлом имеет северовосточное простирание, прослежен на 16 км и насыщен оперяющими трещинами и тектоническими 30нами. Падение разлома субвертикальное, реже крутое, на юг или север; амплитуда перемещения 1,5 км.

Тектонически нарушенные зоны стали благоприятной средой для циркуляции гидротермальных флюидов, генерируемых малыми гранитоидными интрузиями баянкольского субвулканического комплекса $\left(\mathrm{D}_{3} b n\right)$. Это обусловило формирование линейных зон лиственитов с кварцевыми жилами и золотой минерализацией.

На рудопроявлении развиты дорудные кварцтурмалиновые метасоматиты и жилы с W-содержащим рутилом, шеелитом и пиритом (этап I), которые сменяются золото-кварцевыми жилами в березитлиственитовых метасоматитах (этап II). Кварцтурмалиновый высокотемпературный этап включает турмалиновую (1) и турмалин-кварцевую (2) стадии. Кварц-турмалиновые метасоматиты генетически связаны с малыми интрузиями гранодиорит- и тоналитпорфиров баянкольского комплекса $\left(\mathrm{D}_{3} b n\right)$ [2]. Они представляют собой метасоматические породы мощностью до 1-2 м, образованные по кварц-полевошпатовым песчаникам ордовика, сложенные бледно- и светлозеленоватым игольчато-призматическим турмалином с кварц-турмалиновыми и молочно-белыми кварцевыми прожилками последующих стадий (рис. 2). По химическому составу турмалины относятся к промежуточному ряду шерл-дравит-магнезиофойтит с примесью $\mathrm{Gr}_{2} \mathrm{O}_{3}$ до 1,04 мас. \%.
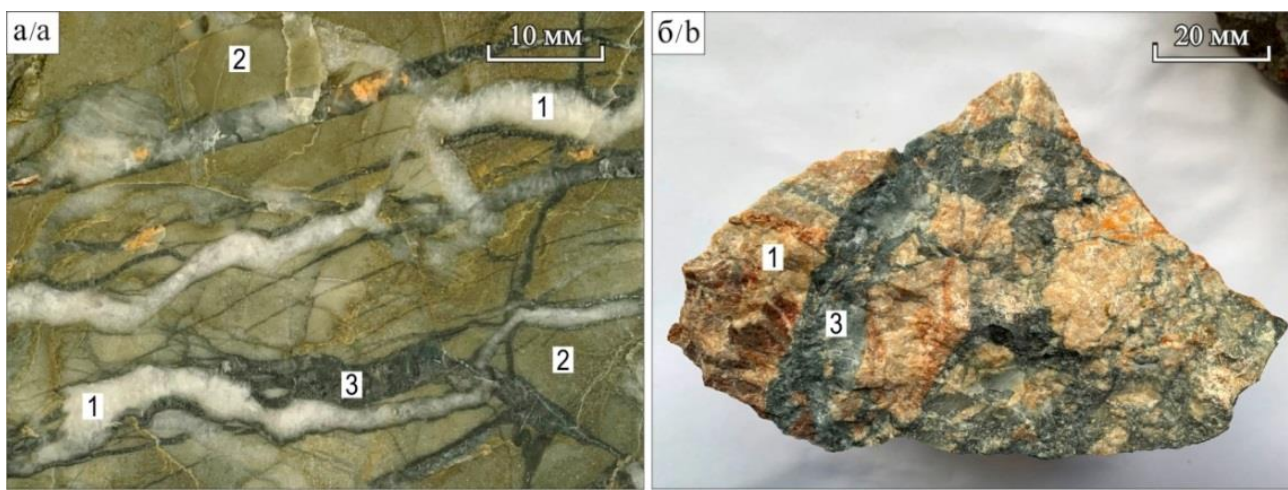

Рис. 2. Квари-турмалиновые метасоматиты и жиль рудопроявления Хаак-Саир: а) квари-турмалиновые (3) и квариевые (1) прожилки в квари-турмалиновом метасоматите; б) квари-турмалиновые (3) жиль в карбонатных породах (1)

Fig. 2. Quartz-tourmaline metasomatites and veins of Khaak-Sair ore occurrence: a) quartz-tourmaline (3) and quartz (1) veinlets in quartz-tourmaline metasomatite; b) quartz-tourmaline (3) veins in carbonate rocks (1)

II золото-сульфидно-кварцевый этап включает дорудные (березит-лиственитовую (1) и пирит-кварцевую (2)), рудные (золото-арсенопирит-сульфосольно-кварцевую (3), золото-ртутисто-селенидно-теллуридно-сульфидно- сульфосольно-кварцевую (4)) и пострудные (хлориттурмалин-кварцевую (5), карбонат-кварцевую (6) и хлорит-кварцевую (7)) стадии. Гипергенные преобразования руд отнесены к III этапу (табл. 1; рис. 3). 
Известия Томского политехнического университета. Инжиниринг георесурсов. 2021. Т. 332. № 12. 148-163

Кужугет Р.В. и др. Золото-сульфиднн-кварцевое рудопроявление Хаак-Саир (Западная Тува): возраст, РТ-параметры, состав ...

Таблица 1. Последовательность минералообразования на рудопроявлении Хаак-Саир

Table 1. Mineral formation sequence of Khaak-Sair ore occurrence

\begin{tabular}{|c|c|c|c|c|c|c|c|c|c|c|}
\hline \multirow{4}{*}{ Минерал/Mineral } & \multicolumn{10}{|c|}{ Этап/Stages } \\
\hline & \multicolumn{2}{|c|}{$\begin{array}{c}\text { Кварц-турмалиновый } \\
\text { Quartz-tourmaline }\end{array}$} & \multicolumn{7}{|c|}{$\begin{array}{l}\text { Гидротермальный золото-сульфидно-кварцевый } \\
\text { Hydrothermal gold-sulfide-quartz }\end{array}$} & \multirow{3}{*}{$\begin{array}{l}\text { Гипергенный } \\
\text { Supergene }\end{array}$} \\
\hline & \multicolumn{9}{|c|}{ Стадия/Substage } & \\
\hline & 1 & 2 & 1 & 2 & 3 & 4 & 5 & 6 & 7 & \\
\hline Кварц/Quartz & $\longrightarrow$ & $\longrightarrow$ & $<$ & $>$ & $\longrightarrow$ & $\longrightarrow$ & $\longrightarrow$ & $\longrightarrow$ & $\longrightarrow$ & \\
\hline Турмалин/Tourmaline & $<$ & 2 & & & & & $\longrightarrow$ & & & \\
\hline Шеелит/Scheelite & $\underline{-}$ & & & $\longrightarrow$ & & & & & & \\
\hline Рутил/Rutile & $\longrightarrow$ & & & & & & & & & \\
\hline Хлорит/Chlorite & $\longrightarrow$ & & $=$ & & & & $\longrightarrow$ & & $=$ & \\
\hline Пирит/Pyrite & $=$ & & $=$ & & $\longrightarrow$ & & & & & \\
\hline Кальцит/Calcite & & & $\longrightarrow$ & & & $=$ & & $\longrightarrow$ & & \\
\hline Доломит/Dolomite & & & $\longrightarrow$ & & $\longrightarrow$ & & & $\longrightarrow$ & & \\
\hline Сидерит/Siderite & & & $\longrightarrow$ & & & & & $\longrightarrow$ & & \\
\hline Анкерит/Ankerite & & & $\longrightarrow$ & & & & & & & \\
\hline Серицит/Sericite & & & $\longrightarrow$ & & & & & & & \\
\hline Парагонит/Paragonite & & & $\longrightarrow$ & & & & & & & \\
\hline Герсдорфит/Gersdorffite & & & $\longrightarrow$ & & - & $\longrightarrow$ & & & & \\
\hline Галенит/Galena & & & & & $\longrightarrow$ & 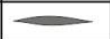 & & & & \\
\hline Сфалерит/Sphalerite & & & & & & - & & & & \\
\hline Арсенопирит/Arsenopyrite & & & & & $<$ & & & & & \\
\hline Халькопирит/Chalcopyrite & & & & & $\longrightarrow$ & $=$ & & & & \\
\hline Блёклые руды/Fahlores & & & & & $\longrightarrow$ & $\longrightarrow$ & & & & \\
\hline Бурнонит/Bournonite & & & & & & 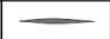 & & & & \\
\hline Борнит/Bornite & & & & & & $\longrightarrow$ & & & & \\
\hline Золото/Native gold & & & & & $\longrightarrow$ & $=$ & & & & $\longrightarrow$ \\
\hline Электрум/Electrum & & & & & $=$ & & & & & \\
\hline Гессит/Hessite & & & & & & - & & & & \\
\hline Hg-золото/Hg-gold & & & & & & - & & & & \\
\hline Hg-электрум/Hg-electrum & & & & & & - & & & & \\
\hline Hg-кюстелит/Hg-kustelite & & & & & & $=$ & & & & \\
\hline Hg-серебро/Hg-silver & & & & & & - & & & & \\
\hline Колорадоит/Coloradoite & & & & & & $=$ & & & & \\
\hline Акантит/Acanthite & & & & & - & - & & & & - \\
\hline Теллуровисмутит/Tellurobismuthite & & & & & & - & & & & \\
\hline Фишессерит/Fischesserite & & & & & & - & & & & \\
\hline Науманнит/Naumannite & & & & & & - & & & & \\
\hline Клаустолит/Clausthalite & & & & & & - & & & & \\
\hline Тиманнит/Tiemannite & & & & & & - & & & & \\
\hline Se-киноварь/Cinnabar & & & & & & - & & & & \\
\hline Se-имитерит/Se-imiterite & & & & & & - & & & & \\
\hline Ялпаит/Jalpaite & & & & & & - & & & & \\
\hline Барит/Baryte & & & & & & - & & & & \\
\hline Гематит/Hematite & & & & $\longrightarrow$ & & & & & $=$ & \\
\hline Ковеллин/Covellite & & & & & & & & & & - \\
\hline Халькозин/Chalcocite & & & & & & & & & & - \\
\hline Малахит/Malachite & & & & & & & & & & $\longrightarrow$ \\
\hline Азурит/Azurite & & & & & & & & & & $\longrightarrow$ \\
\hline Гётит/Goethite & & & & & & & & & & $\longrightarrow$ \\
\hline Скородит/Scorodite & & & & & & & & & & $=$ \\
\hline Серебро/Silver & & & & & & & & & & $\longrightarrow$ \\
\hline Галогениды Ag/Silver halides & & & & & & & & & & - \\
\hline Гипергенные/Supergene & & & & & & & & & & $<$ \\
\hline
\end{tabular}

Примечание. Гипергенные - англезит, церуссит, линарит, конихальцит, брочантит, атакамит и т. д.

Note. Hypergenic - anglesite, cerussite, linarite, conichalcite, brochanite, atacamite, etc. 

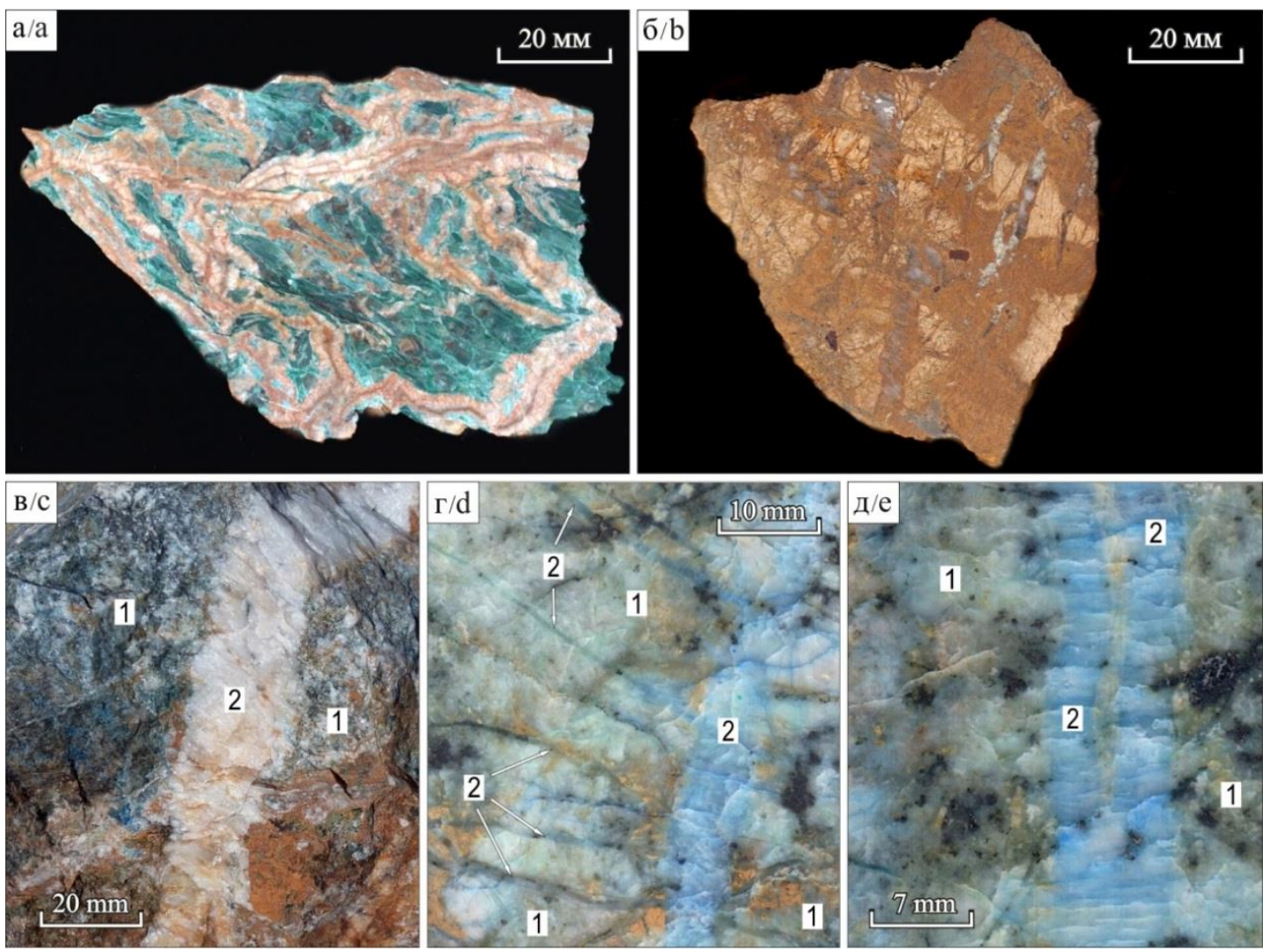

Рис. 3. Листвениты и рудные жилы рудопроявления Хаак-Саир: а, б) листвениты: а) зеленый; б) красновато-бурый в-д) золото-сульфидно-кварцевые прожсили ІІ рудной стадии (2) в минеральных агрегатах I рудной стадии (1)

Fig. 3. Listwanites and ore veins of Khaak-Sair ore occurrence: $a, b)$ listwanites: a) green; b) reddish-brown; $c-e)$ Ausulfide-quartz veins of the late ore substage (2) dissecting the mineral aggregates of the early ore substage (1)

Малосульфидные жилы и жильно-прожилковые зоны с вкрапленной, прожилково-вкрапленной минерализацией развиты в лиственитах, эффузивах и терригенных породах. Они сложены молочно-белым, серовато-белым среднетонкозернистым или халцедоновидным кварцем. Среднее содержание Аи в рудах составляет 2,5 г/т, Ag - 26,55 г/т; наблюдается корреляция $\mathrm{Au} \mathrm{c} \mathrm{Cu}, \mathrm{Sb}, \mathrm{As}, \mathrm{Ag}, \mathrm{B}, \mathrm{Pb}, \mathrm{Ba}, \mathrm{Zn}, \mathrm{Mo}, \mathrm{W}, \mathrm{Bi}, \mathrm{Te}$, $\mathrm{Cd}$ и $\mathrm{Mg}[4]$.

Рудная стадия I включает две минеральные ассоциации: раннюю золото-галенит-арсенопирит-теннантиттетраэдрит-кварцевую с бурнонитом \pm аргентотеннантит-тетраэдрит (Ag до 50,05 мас. \%) и позднюю золотоэлектрум-галенит-халькопирит-тетраэдрит-кварцевую с герсдорфитом \pm пирит \pm борнит \pm кальцит \pm доломит $(\mathrm{FeO}$ до 1,09 мас. $\%) \pm \mathrm{Fe}$-доломит $(\mathrm{FeO}$ от 5,84 до 8,62 мас. \%, $\mathrm{MnO}$ до 0,31 мас. \%).

Минералы ранней ассоциации слагают центральные части жил или самостоятельные жилы и рассечены жилами рудной стадии II (рис. 3, в-d). Последние также образуют две минеральные ассоциации: раннюю золото-гессит-науманнит-теннантит-тетраэдриткварцевую с Нg-золотом (Нg до 2 мас. \%), электрумом, $\mathrm{Hg}$-электрумом, бурнонитом, герсдорфитом (Fe до 1,96 мас. \%), халькопиритом, борнитом, теллуровисмутитом, галенитом (Se до 14,5 мас. \%, Ag до 5 мас. \%), клаусталитом (S до 4,69 мас. \%), науманнитом (S до 1,5 мас. \%), фишессеритом, тиманнитом, колорадоитом $\pm \mathrm{Se}$-имитерит; и позднюю золото- ртутисто-халькопирит-теннантит-тетраэдрит-кварцевую с теннантит-тетраэдритом (Ag до 15,96 мас. \%), тетраэдритом (Ag до 22,76 мас. \%), аргентотетраэдритом (Ag до 40,96 мас. \%), гесситом, акантитом, герсдорфитом (Fе до 3,76 мас. \%, Со до 6,88), Sе-галенитом, науманнитом, S-науманнитом, Hg-золотом, электрумом, $\mathrm{Hg}$-электрумом, $\mathrm{Hg}$-кюстелитом, Аu-содержащим $\mathrm{Hg}$-серебром, баритом, бурнонитом \pm сфалерит $\pm \mathrm{Se}$ киноварь \pm ялпаит \pm кальцит $(\mathrm{FeO}$ до 0,89 мас. \%, $\mathrm{MnO}$ до 0,26).

В рудных жилах широко развиты блеклые руды ряда теннантит-тетраэдрит, низкопробное золото, электрум, кюстелит и их ртутистые разновидности с содержаниями $\mathrm{Hg} 5-10,3-17$ и 5-17,5 мас. \%, соответственно. Пробность золота на рудопроявлении колеблется от 957 до $19 \%$, составляя в среднем $701 \%$.

По составу рудных минералов жил рудопроявление Хаак-Саир отвечает золото-электрум-галенитхалькопирит-сульфосольному типу с $\mathrm{Ag}$-содержащим тетраэдритом (Ag до 22 мас. \%), аргентотетраэдритом (Ag до 40 мас. \%) и минералами ряда $\mathrm{Au}-\mathrm{Ag}-\mathrm{Hg}$.

В коре выветривания рудопроявления развиты многочисленные гипергенные минералы (табл. 1) [4]. Мощность зоны гипергенеза составляет не менее 200 м.

\section{${ }^{40} \mathrm{Ar} /{ }^{39} \mathrm{Ar}$ возраст оруденения на рудопроявлении}

Для определения возраста оруденения был отобран синрудный лиственит (обр. ХС-3, рис. 2, б) из зальбанды золото-сульфидно-сульфосольно-кварцевой 
жилы центрального участка рудопроявления. Прожилково-пятнистый, среднезернистый лиственит имеет красновато-бурую окраску вследствие разложения Fе-содержащих карбонатов, в нем отмечаются кварцевые прожилки, а на их контакте с карбонатами развивается серицит (веерообразные агрегаты из че- шуек размером 0,1-0,3 мм). Лиственит сложен карбонатом (Fе-доломитом, кальцитом) - 60 \%, кварцем $32 \%$, серицитом $\sim 5 \%$, лимонитом по пириту $\sim 3 \%$.

${ }^{40} \mathrm{Ar} /{ }^{39} \mathrm{Ar}$ датирование, выполненное по монофракциям серицита, отобранного вручную, составляет $379,4 \pm 4,4$ млн лет (рис. 4).

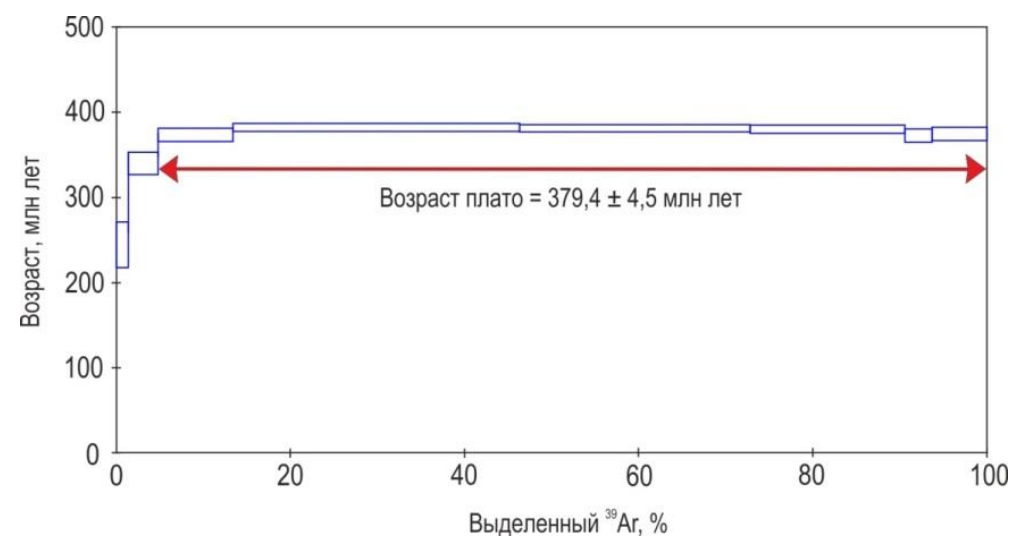

Pис. 4. Результать ${ }^{40} \mathrm{Ar}{ }^{39} \mathrm{Ar}$ датирования серицита из лиственитов рудопроявления Хаак-Саир Fig. 4. ${ }^{40} \mathrm{Ar}{ }^{39} \mathrm{Ar}$ dating of sericite from Khaak-Sair ore occurrence

Полученный возраст синрудных лиственитов рудопроявления хорошо согласуется с ${ }^{40} \mathrm{Ar} /{ }^{39} \mathrm{Ar}$ возрас-

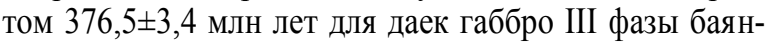
кольского комплекса $\left(\mathrm{D}_{3} b n\right)$ в южной части АМРУ [5].

\section{Условия образования лиственитов и рудных жил}

Для установления условий образования дорудных метасоматитов (лиственитов) и золотоносных жил рудопроявления Хаак-Саир исследованы первичные, псевдовторичные и вторичные флюидные включения в кварце [6]. По фазовому составу они разделены на ассоциации: 1) двухфазные газово-жидкие (VL); 2) трехфазные газово-жидкие с твёрдой фазой (VLS); 3) трехфазные, содержащие газовую фазу, жидкую углекислоту и водный раствор (VLC) (рис. 5). Результаты термометрических исследований приведены в табл. 2 и на рис. 6.
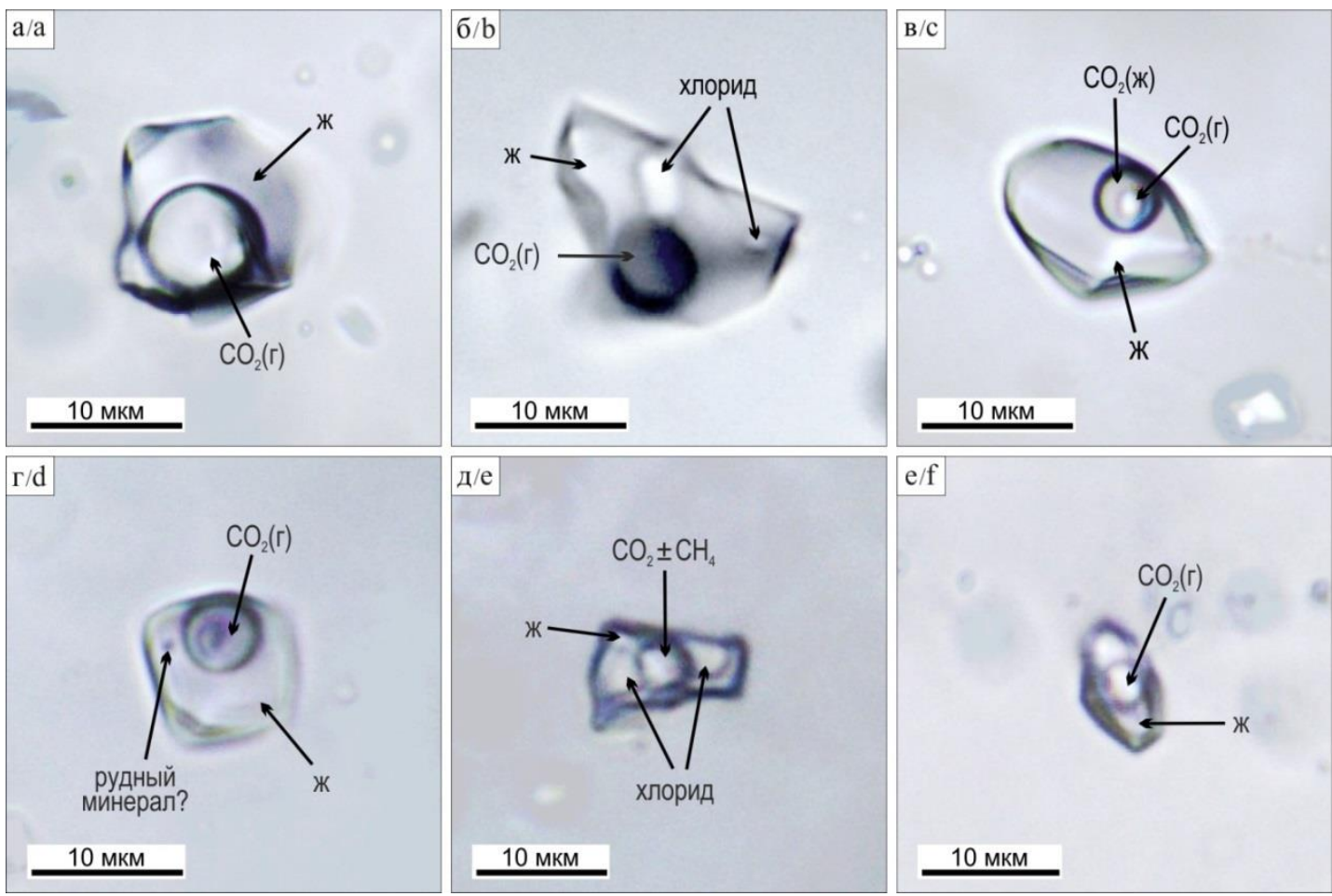

Pис. 5. Флюидные включения в кварие: а) псевдовторичное VL (обр. XC-5); б-г) первичные (обр. XC-7): б) VLS; в, г) VLC; д) первичное VLS (обр. XC-3); е) псевдовторичное VL (обр. ХC-3); ж-жидкая фаза; г-газовая фаза

Fig. 5. Fluid inclusions in quartz: a) pseudosecondary VL (XC-5); b-d) primary (XC-7): b) VLS; $c, d) V L C ;$ ) primary VLS (XC-3); f) pseudosecondary VL (XC-3); ж-liquid phase, z-gas phase 


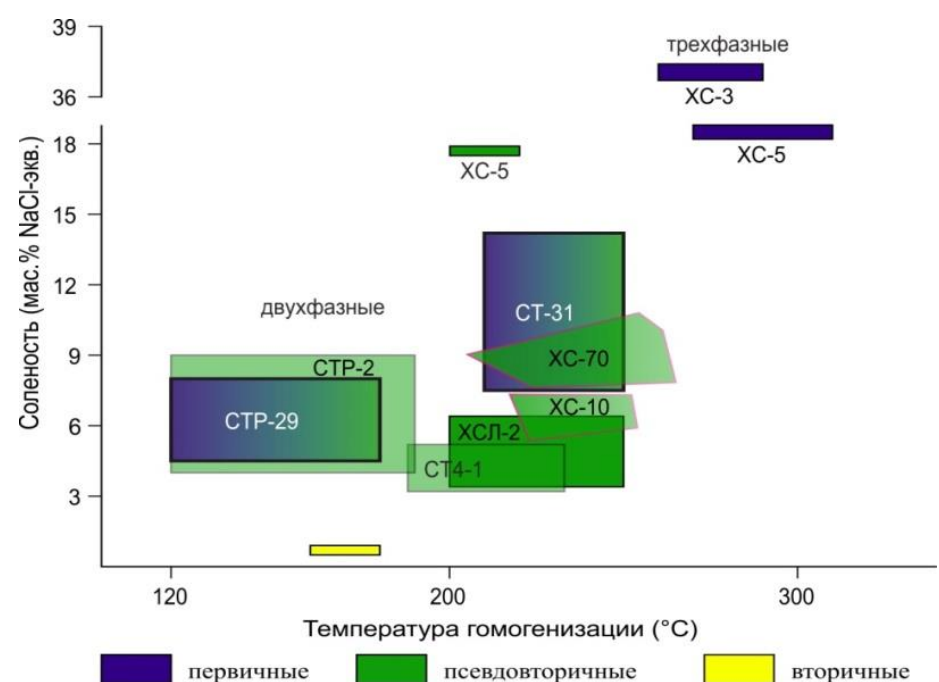

Pис. 6. Диаграмма температур гомогенизации и солености флюидных включений в кварце. Номера образиов - в табл. 2

Fig. 6. Homogenization temperatures vs salinity plot of fluid inclusions in quartz. For sample numbers see Table 2

Таблица 2. Результаты изучения флюидных включений в кварие рудопроявления Хаак-Саир

Table 2. Fluid inclusions data of Khaak-Sair ore occurence

\begin{tabular}{|c|c|c|c|c|c|c|c|c|c|}
\hline $\begin{array}{l}\text { Образец } \\
\text { Sample }\end{array}$ & $\begin{array}{l}\text { Генерация ФВ } \\
\quad \text { (FlA) }\end{array}$ & $\begin{array}{c}\text { Фазовый } \\
\text { состав } \\
\text { (phases) }\end{array}$ & $\mathrm{n}$ & $\begin{array}{l}\mathrm{T}_{\text {гом }},{ }^{\circ} \mathrm{C} \\
\mathrm{T}_{\text {hom }},{ }^{\circ} \mathrm{C}\end{array}$ & $\begin{array}{l}\mathrm{T}_{\text {эвт }},{ }^{\circ} \mathrm{C} \\
\mathrm{T}_{\text {eut }},{ }^{\circ} \mathrm{C}\end{array}$ & $\begin{array}{l}\mathrm{T}_{\text {пл. льда, }},{ }^{\circ} \mathrm{C} \\
\mathrm{T}_{\text {ice melt }},{ }^{\circ} \mathrm{C}\end{array}$ & $\begin{array}{c}\text { Соленость } \\
\text { (мас. \% } \\
\mathrm{NaCl-экв.)} \\
C, \text { wt. \%, } \\
\mathrm{NaCl} \text { equiv }\end{array}$ & $\begin{array}{l}\text { P, бap } \\
\text { P, bar }\end{array}$ & $\begin{array}{l}\text { Солевой состав } \\
\text { Salt composition }\end{array}$ \\
\hline \multicolumn{10}{|c|}{ Листвениты/Listwanites } \\
\hline \multirow{2}{*}{ ХСЛ-2 } & ПВ & VL & 12 & $250-200$ & -15 & $-4--2$ & $3,4-6,5$ & - & $\mathrm{NaCl}-\mathrm{KCl}-\mathrm{H}_{2} \mathrm{O}$ \\
\hline & $\mathrm{B}$ & VL & 20 & $180-160$ & - & $-0,3--0,5$ & $0,5-0,9$ & - & - \\
\hline \multicolumn{10}{|c|}{$\begin{array}{l}\text { Золото-галенит-арсенопирит-теннантит-тетраэдрит-кварцевая жила (I) } \\
\text { Gold-galena-arsenopyrite-tennantite-quartz vein of the early ore substage }\end{array}$} \\
\hline \multirow{3}{*}{$\mathrm{XC}-5$} & $\Pi$ & VL & 10 & $310-270$ & $-28--30$ & $-15,2--14,5$ & $18,2-18,8$ & - & $\begin{array}{l}\mathrm{NaCl}-\mathrm{FeCl}_{2}-\mathrm{H}_{2} \mathrm{O}+ \\
\mathrm{CO}_{2}(\Gamma)\end{array}$ \\
\hline & ПВ & VL & 18 & $220-200$ & $-21--25$ & $-14,2--13,7$ & $17,5-17,9$ & - & $\begin{array}{l}\mathrm{NaCl}-\mathrm{FeCl}_{2}-\mathrm{H}_{2} \mathrm{O}+ \\
\mathrm{CO}_{2}(\Gamma)\end{array}$ \\
\hline & $\mathrm{B}$ & $\mathrm{VL}$ & 22 & $180-160$ & - & - & - & - & - \\
\hline \multicolumn{10}{|c|}{$\begin{array}{l}\text { Золото-электрум-галенит-халькопирит-тетраэдрит-кварцевые жилы (I) } \\
\text { Gold-electrum-galena-chalcopyrite-tennantite-tetrahedrite-quartz veins of the early ore substage }\end{array}$} \\
\hline \multirow{2}{*}{$\mathrm{XC}-7$} & $\Pi$ & VLC & 10 & $280-260$ & - & - & - & $0,75-0,6$ & $\mathrm{CO}_{2}(\Gamma+\%)$ \\
\hline & $\Pi$ & VLS & 8 & $270-260 *$ & - & - & - & - & chlorides- $\mathrm{H}_{2} \mathrm{O}+\mathrm{CO}_{2}(\mathrm{\Gamma})$ \\
\hline CT-31 & ПВ & VL & 67 & $250-210$ & $-22--24$ & $-10,3--4,8$ & $7,5-14,2$ & - & $\begin{array}{c}\mathrm{H}_{2} \mathrm{O} \pm \mathrm{CO}_{2}(\Gamma)+ \\
\mathrm{NaCl}-\mathrm{KCl}-\mathrm{H}_{2} \mathrm{O} \\
\end{array}$ \\
\hline \multicolumn{10}{|c|}{$\begin{array}{l}\text { Золото-гессит-науманнит-теннантит-тетраэдрит-кварцевые жилы (II) } \\
\text { Gold-hessite-naumannite-tennantite-tetrahedrite-quartz veins of the late ore substage }\end{array}$} \\
\hline \multirow{5}{*}{$\begin{array}{l}\mathrm{XC}-8 \\
\mathrm{XC}-3\end{array}$} & \multirow[b]{2}{*}{$\Pi$} & VL & 20 & $320-300$ & - & - & - & - & $+\mathrm{CO}_{2}(\Gamma)$ \\
\hline & & VLS & 13 & $275-270^{*}$ & - & - & - & - & $\begin{array}{c}\text { chlorides- } \\
\mathrm{H}_{2} \mathrm{O}+\mathrm{CO}_{2} \pm \mathrm{CH}_{4}(\Gamma)\end{array}$ \\
\hline & ПВ & VL & 24 & $270-250$ & - & - & - & - & $+\mathrm{CO}_{2}(\Gamma)$ \\
\hline & $\Pi$ & VLS & 14 & $290-280$ & - & - & $36,7-37,4$ & - & chlorides $-\mathrm{H}_{2} \mathrm{O}+\mathrm{CO}_{2}(\mathrm{\Gamma})$ \\
\hline & ПВ & $\mathrm{VL}$ & 25 & $230-190$ & - & - & - & - & chlorides $+\mathrm{CO}_{2}(\Gamma)$ \\
\hline \multicolumn{10}{|c|}{$\begin{array}{l}\text { Золото-ртутисто-халькопирит-теннантит-тетраэдрит-кварцевые жилы (II) } \\
\text { Gold-mercury-chalcopyrite-tetrahedrite-quartz veins of the late ore substage }\end{array}$} \\
\hline \multirow{3}{*}{$\begin{array}{l}\text { CTP-2 } \\
\text { CT4-1, } \\
\text { CT-29 }\end{array}$} & $\Pi$ & VL & 31 & $230-180$ & $-21--24$ & $-2,5--5,0$ & $4,5-8,0$ & - & $\mathrm{NaCl}-\mathrm{KCl}-\mathrm{H}_{2} \mathrm{O}$ \\
\hline & ПВ & VLC & 11 & $190-120$ & $-19--23$ & $-2,5--6,0$ & $4-9$ & 0,5 & $\begin{array}{c}\mathrm{NaCl}-\mathrm{H}_{2} \mathrm{O} \\
\mathrm{NaCl}-\mathrm{KCl}-\mathrm{H}_{2} \mathrm{O}\end{array}$ \\
\hline & ПВ & VL & 48 & $180-120$ & $-21--24$ & $-2,5--5,0$ & $4,5-8,0$ & - & $\begin{array}{c}\mathrm{NaCl}-\mathrm{H}_{2} \mathrm{O} \\
\mathrm{NaCl}-\mathrm{KCl}-\mathrm{H}_{2} \mathrm{O}\end{array}$ \\
\hline \multicolumn{10}{|c|}{ Пострудные кварц-турмалиновые жилы / Post-ore quartz-tourmaline veins } \\
\hline XC-70 & ПВ & VL & 45 & $265-210$ & $-22--24$ & $-6,4--8$ & $8-10,4$ & - & $\mathrm{NaCl}-\mathrm{KCl}-\mathrm{H}_{2} \mathrm{O}$ \\
\hline \multirow{2}{*}{$\mathrm{XC}-10$} & ПВ & $\mathrm{VL}$ & 23 & $255-210$ & $-21--23$ & $-3,3--5,1$ & $5,5-8$ & - & $\mathrm{NaCl}-\mathrm{KCl}-\mathrm{H}_{2} \mathrm{O}$ \\
\hline & $\Pi$ & $\mathrm{VL}$ & 11 & $240-252$ & $-33--34$ & $-3,8--5$ & $6-7,9$ & - & $\mathrm{MgCl}_{2}-\mathrm{H}_{2} \mathrm{O}$ \\
\hline
\end{tabular}

Примечание: $n$ - количество анализов, $T_{\text {гом }}$ - температура гомогенизачии, $T_{\text {экт }}-$ температура эвтектики, $T_{n z \text { льда }}-$ температура плавления льда. Включения: П - первичные, ПВ - псевдовторичные, $B$ - вторичные; * - включения декрипитировали; ж-жидкая фаза, г-газовая фаза.

Note: $n$-number of analyzes, $T_{\text {hom }}-$ homogenization temperatures, $T_{\text {eut }}-$ eutectic temperatures; $T_{\text {ice melt }}-$ final melting temperatures; $\Pi$ - primary inclusions, $\Pi B$ - pseudosecondary inclusions, $B$ - secondary inclusions; * - inclusions were decrypted; ж-liquid, 2 - gas. 
В кварце лиственитов выявлены псевдовторичные и вторичные VL флюидные включения. Первые тяготеют к трещинам в кварце, образовавшимся в процессе его отложения и не выходящим за пределы крупных зерен. Они имеют овальную и изометричную форму, размеры 9-13 мкм с долей газовой фазы до 40 об. \%. Псевдовторичные включения содержат хлориды натрия и калия $\left(\mathrm{T}_{\text {эвт }}=-15^{\circ} \mathrm{C}\right)$. Концентрации солей по температурам плавления льда $\left(\mathrm{T}_{\text {пл. }}=-4 \ldots-2{ }^{\circ} \mathrm{C}\right)$ составляют 3,4-6,5 мас. \% NaCl-экв. Температуры гомогенизации включений в жидкую фазу составили $220-250{ }^{\circ} \mathrm{C}$.

Вторичные включения имеют округлую и удлиненную форму с неровными краями, размеры до 5 мкм; доля газовой фазы составляет до 15 об. \%. Для них получены концентрации солей 0,5-0,9 мас. \% $\mathrm{NaCl}$-экв. $\left(\mathrm{T}_{\text {пл. }}=-0,3 \ldots-0,5^{\circ} \mathrm{C}\right)$ и температуры гомогенизации (в жидкость) $160-180{ }^{\circ} \mathrm{C}$ (табл. 2).

В кварце золото-галенит-арсенопирит-теннантиттеннантит-кварцевой жилы I рудной стадии проанализированы газово-жидкие (VL) включения нескольких генераций: первичные, псевдовторичные и вторичные. Первичные включения встречаются обособленно или в виде малочисленных групп, имеют изометричную форму с элементами кристаллографических граней и размеры до 12 мкм. Псевдовторичные включения трассируют залеченные трещины в кристаллах кварца и характеризуются удлиненной формой и размерами 8-12 мкм. Вторичные включения имеют изометричную или округлую форму и размеры 3-7 мкм и маркируют поздние прожилки в кварце. По данным рамановской спектроскопии, первичные VL включения в газовой фазе содержат углекислоту. Для них получены температуры эвтектики, равные $-30 . .-$ $28{ }^{\circ} \mathrm{C}$, и температуры плавления льда от $-15,2$ до $14,5{ }^{\circ} \mathrm{C}$. Эти данные отвечают хлоридному раствору, содержащему ионы $\mathrm{Fe}$ и $\mathrm{Na}$, с концентрацией 18,218,8 мас. \% NaCl-экв. Температуры гомогенизации (в жидкость) составили $270-310^{\circ} \mathrm{C}$. Псевдовторичные VL включения содержат раствор хлоридов $\mathrm{Fe}$ и $\mathrm{Na}$ c концентрацией 17,5-17,9 мас. \% $\mathrm{NaCl}$-экв. $\left(\mathrm{T}_{\text {эвт. }}=-27 \ldots-25^{\circ} \mathrm{C} ; \mathrm{T}_{\text {пл. }}=-14,2 \ldots-13,7^{\circ} \mathrm{C}\right)$. Газовая фаза представлена углекислотой. Температуры их гомогенизации (в жидкость) составляют 200-220 ${ }^{\circ} \mathrm{C}$. Вторичные VL включения гомогенизируются в жидкую фазу при $160-180{ }^{\circ} \mathrm{C}$ (табл. 2).

В кварце золото-электрум-галенит-халькопириттетраэдрит-кварцевой жилы I рудной стадии проанализированы первичные VLC и VLS и псевдовторичные VL включения. Первичные включения имеют округлую изометричную, реже остроугольную или вытянутую форму с элементами кристаллографических граней и размеры 7-18 мкм. Солевой состав растворов, оцененный по температурам эвтектики, соответствует хлоридному с ионами $\mathrm{Na}$ и К с концентрациями 7,5-14 мас. \% NaCl-экв. Температуры гомогенизации включений (в жидкость) составляют $210-250{ }^{\circ} \mathrm{C}$. Псевдовторичные включения имеют изометричную и удлиненную форму и размеры 5-9 мкм. Газовая фаза первичных VLS включений представлена углекислотой, минеральная фаза - светлоокрашен- ная изотропная кубического габитуса, вероятно, является хлоридом. При нагревании включения декрипитировали при температурах $260-270{ }^{\circ} \mathrm{C}$. В первичных VLC включениях при комнатной температуре газовые фазы не наблюдались. При их охлаждении наблюдалось отделение газовой вакуоли, которая переходила обратно в газовую фазу при температурах $+8 \ldots+9,2^{\circ} \mathrm{C}$. Температуры гомогенизации первичных VLC включений варьируют от 260 до $280{ }^{\circ} \mathrm{C}$. Полученным температурам гомогенизации углекислоты и полной гомогенизации включений соответствуют

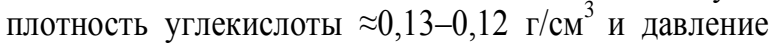
750-600 бар. В отдельных случаях во включениях этого типа наблюдается черная минеральная фаза, вероятно, представленная рудным минералом (рис. 3, 2). Сонахождение пересыщенных VLS и существенно углекислотных VLC включений свидетельствует о процессе кипения флюида [7]. Псевдовторичные VL включения в газовой фазе содержат углекислоту, иногда отмечается водяной пар. Температуры гомогенизации установить не удалось, так как при нагреве до температур 190-250 ${ }^{\circ} \mathrm{C}$ включения декрипитировали (табл. 2).

В кварце золото-гессит-науманнит-теннантиттетраэдрит-кварцевой жилы II рудной стадии изучены первичные VL и VLS и псевдовторичные VL включения, расположенные в виде групп или одиночно, размером 4-7 мкм с элементами кристаллографических граней. Первичные VL включения в газовой фазе содержат углекислоту. Для них установлены температуры гомогенизации (в жидкость) $300-320{ }^{\circ} \mathrm{C}$. Первичные VLS включения имеют изометричную и удлиненную форму и размеры до 20 мкм. Они содержат изотропную светлоокрашенную минеральную фазу, вероятно, представленную хлоридом. В отдельных случаях во включениях находится несколько твердых фаз. Газовая фаза первичных VLS включений представлена $\mathrm{CO}_{2}$ с примесью $\mathrm{CH}_{4}$. Их температуры гомогенизации (в жидкость) равны $280-290{ }^{\circ} \mathrm{C}$, а концентрации солей - 36,7-37,4 мас. \% NaCl-экв. В ряде случаев гомогенизация включений не была достигнута, получены температуры декрипитации VLS включений, равные $270-275^{\circ} \mathrm{C}$. Псевдовторичные VL включения характеризуются изометричной формой и размерами 3-5 (до 12) мкм. Они также содержат углекислоту в составе газовой фазы, однако характеризуются более низкими температурами гомогенизации (в жидкость) - 190-270 $\mathrm{C}$ (табл. 2).

В кварце золото-ртутисто-халькопирит-теннантиттетраэдрит-кварцевых жил II рудной стадии изучены VLC и VL первичные и псевдовторичные включения. Включения имеют округлую или вытянутую форму и размеры до 15 мкм. Солевой состав, оцененный по температурам эвтектики, соответствует хлоридному флюиду с ионами $\mathrm{Na}$ и $\mathrm{K}$ с концентрациями 3,2-5,2 мас. \% NaCl-экв. Температуры их гомогенизации (в жидкость) составили 230-180 ${ }^{\circ} \mathrm{C}$. Жидкая фаза в трехфазных VLC включениях представлена углекислотой. Температура плавления углекислоты $\left(-56,6{ }^{\circ} \mathrm{C}\right)$ свидетельствует об отсутствии примесей других газов. Температуры гомогенизации $\mathrm{CO}_{2}$ в 
жидкую фазу $\left(26,5-28,7 \quad{ }^{\circ} \mathrm{C}\right) \quad$ и $\quad$ полной $\left(230-180{ }^{\circ} \mathrm{C}\right)$ гомогенизации VLC включений в жидкость указывают на давление флюида 0,5 кбар. Флюид содержит хлориды Na и К. Температуры гомогенизации (в жидкость) псевдовторичных VL и VLC включений составляют $190-120^{\circ} \mathrm{C}$.

В кварце пострудных кварц-турмалиновых прожилков изучены первичные и псевдовторичные двухфазные VL флюидные включения. Они имеют размеры до 15 мкм, овальную либо округлую форму с крупными газовыми вакуолями (до 20-25 об. \%). Плавление эвтектики растворов первичных включений происходило при температурах от -33 до $33,9{ }^{\circ} \mathrm{C}$, следовательно, флюид имеет $\mathrm{MgCl}_{2}-\mathrm{H}_{2} \mathrm{O}$ состав. Температуры гомогенизации (в жидкость) варьируют от 240 до $250{ }^{\circ} \mathrm{C}$. Соленость флюида составляет 6-8 мас. \% NaCl-экв. Температуры эвтектики псевдовторичных включений образуют интервал $-21 \ldots-$ $24{ }^{\circ} \mathrm{C}$, что отвечает $\mathrm{NaCl}-\mathrm{KCl}_{2}-\mathrm{H}_{2} \mathrm{O}$ флюиду с концентрациями солей 5,5-10 мас. \%. Температуры гомогенизации составили $210-265{ }^{\circ} \mathrm{C}$.

\section{Геохимические особенности флюида}

Валовый анализ водных и газовых вытяжек из флюидных включений из монофракций кварца по методике [8] дал информацию об элементном составе флюида рудных стадий рудопроявления Хаак-Саир. Во включениях в кварце I рудной стадии (табл. 3) среди катионов (г/кг $\left.\mathrm{H}_{2} \mathrm{O}\right)$ преобладает $\mathrm{Na}(4,54)$, в подчиненном количестве находятся $\mathrm{K}(0,24), \mathrm{Ca}(0,14)$ и $\mathrm{Mg}(0,004)$. Установлены значимые количества (г/кг $\left.\mathrm{H}_{2} \mathrm{O}\right): \mathrm{CO}_{2}(131), \mathrm{HCO}_{3}^{-}(10,43), \mathrm{Cl}^{-}(1,39)$ и $\mathrm{CH}_{4}(0,08)$ Из микрокомпонентов в значительных количествах присутствует (мг/кг р-ра): В $(393,6), \mathrm{Sb}(134,7), \mathrm{As}$ $(112,5), \mathrm{Ba}(18), \mathrm{Sr}(15,4), \mathrm{Fe}(5,5), \mathrm{Cu}(1,12)$ и $\mathrm{Ag}$ $(1,73)$.

Во включениях в кварце II рудной стадии также преобладает (г/кг $\left.\mathrm{H}_{2} \mathrm{O}\right) \mathrm{Na}(4,3-7,17)$, а $\mathrm{Ca}(0,00-1,8)$, $\mathrm{K}(0,37-1,6)$ и $\mathrm{Mg}(0,2-0,46)$ находятся в подчиненном количестве. Содержания летучих компонентов флюида выявлены в следующих концентрациях (г/кг $\left.\mathrm{H}_{2} \mathrm{O}\right)$ : $\mathrm{CO}_{2}(27,8-154,9), \mathrm{HCO}_{3}^{-}(17,69-20,68), \mathrm{Cl}^{-}(0,34-1,74)$ и $\mathrm{CH}_{4}(0,071-0,236)$. Из микрокомпонентов в значимых количествах присутствуют (мг/кг р-ра): Sb (1539-7441), As (120-804), B (123-1076), Ba (449-2807), Sr (41,7-78,8), $\mathrm{Fe}(8,3-26,7), \mathrm{Mn}(4,1-25,2), \mathrm{Pb}(0,09-62)$, Ni $(2,8-26,8)$, Мо $(3-6,7), \mathrm{Cu}(10,2), \mathrm{Ag}(2-6,24), \mathrm{W}(6,24)$ и Вi (до 0,02).

Средний химический состав флюида рудопроявления Хаак-Саир показан на рис. 7.

\section{Изотопный состав S, O и C}

Значение $\delta^{34} \mathrm{~S}$ галенита из жил I рудной стадии составляет $-0,6 \%$, II рудной стадии $--0,4 \%$, т. е. величины изотопного состава характеризуются устойчивыми околонулевыми значениями в интервале от 0,6 до $-0,4 \%$.

Значения $\delta^{34} \mathrm{~S}_{\mathrm{H}_{2} \mathrm{~S}}$ флюида в соответствии с уравнением фракционирования $[9,10]$ I рудной стадии находятся в интервале $+1,5 \ldots+2,1 \%$ o $\left(T=280-210^{\circ} \mathrm{C}\right)$,
II рудной стадии $-+1,6 \ldots+2,6 \%$ \% $\left(T=290-190{ }^{\circ} \mathrm{C}\right)$, что свидетельствует об участии магматической серы и магматическом генезисе флюида [9-12].

Величина $\delta^{18} \mathrm{O}$ кварца рудных жил рудопроявления изменяется от 17,0 до 17,4 \%о, в том числе в кварце ранней рудной стадии - от 17,2 до 17,4 \%о, II - 17,0\% [13]. Значения $\delta^{18} \mathrm{O}$ флюида в соответствии с уравнением фракционирования $[14,15]$ I рудной стадии находятся в интервале $+8,0 \ldots+5,7 \%$ \% $\left(T=250-210^{\circ} \mathrm{C}\right)$, II рудной стадии $-+6,7 \ldots-1,7 \%$ \% $\left(T=230-120^{\circ} \mathrm{C}\right)$.

Таблица 3. Валовый состав растворов флюидных включений в кварие

Table 3. Bulk fluid inclusion composition in quartz

\begin{tabular}{|c|c|c|c|c|c|}
\hline \multirow{4}{*}{$\begin{array}{l}\text { Компоненты } \\
\text { Components }\end{array}$} & \multicolumn{4}{|c|}{ Рудные стадии/Ore substages } & \multirow{4}{*}{$\begin{array}{l}\text { Среднее } \\
\text { Average }\end{array}$} \\
\hline & I & & II & & \\
\hline & \multicolumn{4}{|c|}{ Проба/Sample } & \\
\hline & CT-31-8 & CT-31-6 & CT4-1 & CT-29 & \\
\hline \multicolumn{6}{|c|}{$\begin{array}{c}\text { Макрокомпонентыл, г/кг воды } \\
\text { Bulk components, } \mathrm{g} / \mathrm{kg} \mathrm{H}_{2} \mathrm{O} \\
\end{array}$} \\
\hline $\mathrm{CO}_{2}$ & 131,36 & 154,99 & 27,85 & 63,91 & 94,53 \\
\hline $\mathrm{CH}_{4}$ & 0,075 & 0,071 & 0,129 & 0,236 & 0,13 \\
\hline $\mathrm{Cl}^{-}$ & 1,39 & 0,34 & 1,74 & 0,72 & 1,05 \\
\hline $\mathrm{HCO}_{3}^{-}$ & 10,43 & 17,69 & 18,40 & 20,68 & 16,80 \\
\hline $\mathrm{Na}$ & 4,54 & 4,66 & 7,17 & 4,38 & 5,19 \\
\hline K & 0,24 & 0,37 & 0,85 & 1,61 & 0,77 \\
\hline $\mathrm{Ca}$ & 0,14 & 1,40 & 0,00 & 1,80 & 0,83 \\
\hline $\mathrm{Mg}$ & 0,004 & 0,210 & 0,212 & 0,457 & 0,22 \\
\hline \multicolumn{6}{|c|}{$\begin{array}{l}\text { Микрокомпоненты, } 10^{-3} \text { г/кг воды } \\
\text { Trace elements, } 10^{-3} \mathrm{~g} / \mathrm{kg} \mathrm{H} \mathrm{H}_{2} \mathrm{O}\end{array}$} \\
\hline $\mathrm{Sb}$ & 134,73 & 1539,05 & - & 7441,08 & 2278,72 \\
\hline $\mathrm{Ba}$ & 18,01 & 449,57 & 1428,77 & 2807,79 & 1176,04 \\
\hline $\mathrm{B}$ & 393,64 & 679,13 & 122,57 & 1076,02 & 567,84 \\
\hline As & 112,25 & 288,2 & 119,93 & 804,44 & 331,21 \\
\hline $\mathrm{Sr}$ & 15,36 & 41,75 & 66,37 & 78,81 & 50,57 \\
\hline $\mathrm{Fe}$ & 5,56 & 8,32 & 20,58 & 26,67 & 15,28 \\
\hline $\mathrm{Mn}$ & 1 & 4,15 & 25,2 & 27,49 & 14,46 \\
\hline $\mathrm{Pb}$ & 0,1 & 2,42 & 0,09 & 62,16 & 16,19 \\
\hline Mo & - & 3,07 & 6,59 & 6,47 & 4,033 \\
\hline $\mathrm{Li}$ & 1,55 & 3,24 & 5,73 & 5,26 & 3,95 \\
\hline $\mathrm{Ni}$ & 1,98 & 2,84 & 26,76 & 3,43 & 8,75 \\
\hline $\mathrm{Cu}$ & 1,12 & - & 10,2 & - & 2,83 \\
\hline $\mathrm{Zn}$ & - & 141,71 & - & - & 35,43 \\
\hline $\mathrm{Ag}$ & 1,73 & 2,03 & 6,24 & 4,31 & 3,58 \\
\hline W & - & 0,77 & 6,24 & - & 1,75 \\
\hline $\mathrm{Rb}$ & 0,23 & 0,79 & 0,85 & 2,13 & 1 \\
\hline $\mathrm{Cr}$ & 0,09 & 0,29 & 1,55 & 0,49 & 0,61 \\
\hline $\mathrm{Cd}$ & 0,27 & 1,03 & 0,21 & 0,27 & 0,45 \\
\hline Cs & 0,38 & 0,45 & 0,35 & 0,23 & 0,35 \\
\hline Co & 0,07 & 0,49 & 0,36 & 0,31 & 0,31 \\
\hline $\mathrm{Hg}$ & 0,24 & - & - & 0,76 & 0,25 \\
\hline $\mathrm{Ge}$ & 0,1 & 0,06 & 0,02 & 0,18 & 0,09 \\
\hline $\mathrm{Au}$ & 0,02 & 0,05 & - & 0,14 & 0,05 \\
\hline $\mathrm{Tl}$ & - & 0,01 & 0,02 & 0,05 & 0,02 \\
\hline $\mathrm{Bi}$ & - & 0,01 & 0,02 & - & 0.008 \\
\hline REE & 0,02 & 0,26 & 0,96 & 0,58 & 0,46 \\
\hline $\mathrm{Na} / \mathrm{K}$ & 18,92 & 12,59 & 8,47 & 2,72 & 10,68 \\
\hline $\mathrm{CO}_{2} / \mathrm{CH}_{4}$ & 1751,47 & 2182,96 & 215,9 & 270,81 & 1105,29 \\
\hline $\mathrm{K} / \mathrm{Rb}$ & 1043 & 468 & 1000 & 756 & 816 \\
\hline
\end{tabular}

Примечание. Анализы выполнены в ФГУП ЦНИГРИ (аналитик С.Г. Кряжев). «-»-не обнаружено.

Note. The analyses are performed in FSBI TSNIGRI (operator S.G. Kryazhev). «-»-below the detection limit. 


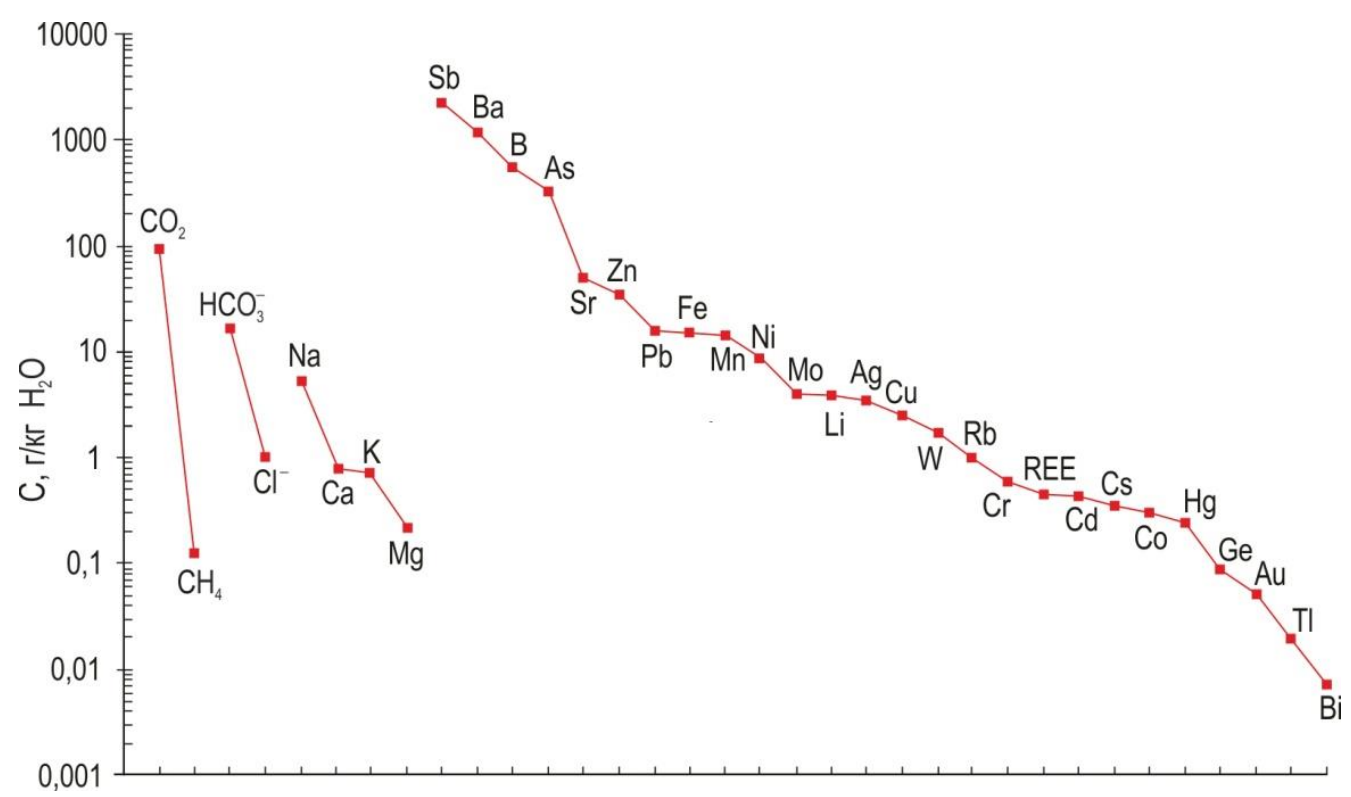

Рис. 7. Средний химический состав флюида рудопроявления Хаак-Саир.

Fig. 7. Average chemical fluid composition of Khaak-Sair ore occurrence

Величины $\delta^{18} \mathrm{O}$ доломита I рудной стадии находятся в интервале от $+17,4$ до $+17,8 \%$, кальцита II рудной стадии - +16,5\%. Изотопные составы $\delta^{18} \mathrm{O}$ флюида, из которого отлагался доломит, в соответствии с уравнением фракционирования [9, 10], образуют интервал от $+8,1$ до $+5,7 \%$ \% $\left(T=250-210^{\circ} \mathrm{C}\right)$, кальцит $--2,2 \ldots+5,9 \%\left(T=230-120{ }^{\circ} \mathrm{C}\right)$. Соответственно, изотопный состав кислорода флюида, ответственного за отложение минеральных ассоциаций І рудной стадии, характеризуется значениями от $+8,1$ до $+5,7 \%$, II рудной стадии $-+6,7$...-2,2\% (рис. 8 ).

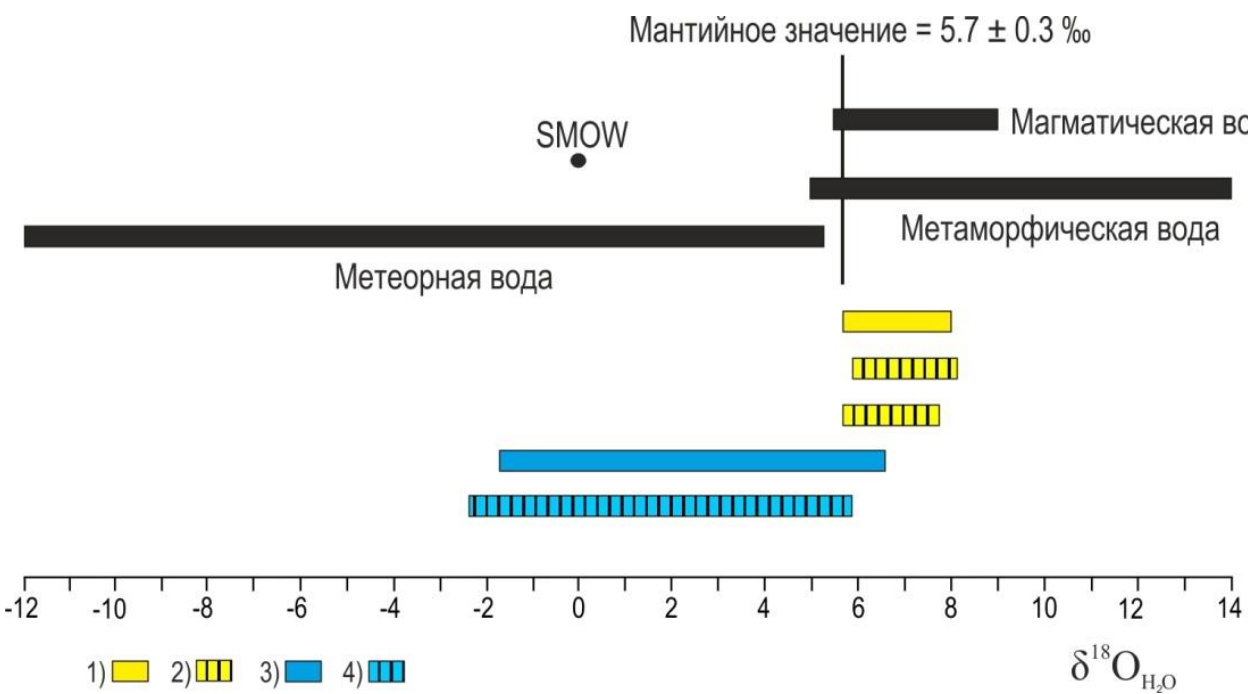

Pис. 8. Изотопный состав кислорода флюида I (1 - квари, 2 - доломит) и II (3 - квари, 4 - кальциит) рудных стадий рудопроявления Хаак-Саир

Fig. 8. Oxygen isotopic composition of the fluid of I (1 - quartz, 2 -dolomite) and II (3-quartz, 4 - calcite) ore substages of Khaak-Sair ore occurrence

Изотопные данные кислорода флюида I рудной стадии попадают в область значений для флюидов как магматического, так и метаморфического происхождения, но не выходят за пределы поля магматического флюида. Эти данные и значения $\delta^{34} \mathrm{~S}_{\mathrm{H}_{2} \mathrm{~S}}$ флюида от $+1,5$ до $+2,1 \%$, предполагают поступление воды из магматического источника $\left(\delta^{18} \mathrm{O}=+5,5 \ldots+9 \%\right)$. Изотопные данные кислорода флюида (от $+6,7$ до $-2,2 \%$ ) II рудной стадии указывают на смешение рудонос- ных магматических флюидов с метеорной водой (рис. 6).

Величины $\delta^{13} \mathrm{C}$ доломита II рудной стадии варьируют от $-0,4$ до $-0,7 \%$; кальцита II рудной стадии составляет $-0,3 \%$, и рассчитанные величины изотопного состава $\delta^{13} \mathrm{C}$ во флюиде, в соответствии с уравнениями $[16,17]$, изменяются от $-1,2$ до $+0,1 \%$ $\left(\mathrm{T}=250-210{ }^{\circ} \mathrm{C}\right)$ и от $-3,3$ до $+0,5 \%$ 。 $\left(T=230-120^{\circ} \mathrm{C}\right)$, соответственно. 
Изотопный состав $\delta^{13} \mathrm{C}$ флюида (от $-3,3$ до $+0,5 \%$ ) предполагает поступление в гидротермальную систему углерода из разных источников: гранитоидных магм и заимствование его из вмещающих карбонатных и терригенных пород. Отметим, что значения мантийного $\delta^{13} \mathrm{C}$ составляют от -7 до $-2 \%$, гранитоидных магм $--6 \ldots-2 \%$ [ $[18]$.

\section{Обсуждение результатов}

Результаты ${ }^{40} \mathrm{Ar} /{ }^{39} \mathrm{Ar}$ датирования синрудных лиственитов $(379,4 \pm 4,4$ млн лет) рудопроявления хорошо согласуются с ${ }^{40} \mathrm{Ar} /{ }^{39} \mathrm{Ar}$ возрастом $(376,5 \pm 3,4$ млн лет) даек габбро III фазы баянкольского комплекса $\left(\mathrm{D}_{3} \mathrm{bn}\right)$, что подтверждает парагенетическую связь оруденения с баянкольским комплексом позднего девона.

Проведенные исследования флюидных включений в кварце методами термометрии и рамановской спектроскопии показали, что сопряженные листвениты отлагались при участии $\mathrm{Na}-\mathrm{K}$ хлоридного флюида с соленостью 3,5-6,5 мас. \% NaCl-экв. при температуpax не менее $200-250{ }^{\circ} \mathrm{C}$. Эти данные согласуются с ранее полученными результатами по флюидным включениям в кварце из лиственитов Сарыгдашского рудного поля (Хаак-Саирского рудопроявления) [19], установившими, что турмалинсодержащие листвениты образовались при участии углекислых растворов при $150-325^{\circ} \mathrm{C}$ и Р $0,4 \ldots 1,0$ кбар ( $1,2 \ldots 3$ км). Отметим, что по данным Ґ20† при близких температурах $\left(150-275{ }^{\circ} \mathrm{C}\right)$ и солености $6-8$ мас. \% $\mathrm{NaCl}$ экв. образовались турмалинсодержание листвениты Эдыгейского гипербазитового массива, расположенного в 25 км к ЮЗ от рудопроявления Хаак-Саир.

Ранние рудные жилы рудопроявления с золотом, электрумом, арсенопиритом и блеклыми рудами отлагались при $\mathrm{P} \sim 0,6-0,75$ кбар ( 1,8-2,3 км) водноуглекислотным флюидом состава $\mathrm{NaCl}-\mathrm{KCl}-\mathrm{H}_{2} \mathrm{O}$, $\mathrm{NaCl}-\mathrm{FeCl}_{2}-\mathrm{H}_{2} \mathrm{O} \pm \mathrm{CO}_{2}$ с концентрациями солей $7,5-18,8$ мас. \% NaCl-экв. при $210-310{ }^{\circ} \mathrm{C}$.

Поздние рудные жилы с ртутистым золотом, селенидами $\mathrm{Au}, \mathrm{Ag}$ и $\mathrm{Hg}$, гесситом, акантитом, бурнонитом, аргентотетраэдритом и баритом отлагались при P 0,5 кбар ( 1,5 км) при участии флюида состава $\mathrm{NaCl}-\mathrm{H}_{2} \mathrm{O}, \mathrm{NaCl}-\mathrm{KCl}-\mathrm{H}_{2} \mathrm{O} \pm \mathrm{CO}_{2} \pm \mathrm{CH}_{4}$ с концентрациями солей 4-32,9 мас. \%. при $120-320^{\circ} \mathrm{C}$.

Сосуществующие однофазные газовые, жидкостные и более концентрированные VL и VLS включения свидетельствуют о гетерогенизации флюида [21], что позволяет считать температуры гомогенизации включений истинными температурами флюида при минералообразовании. В свою очередь, наличие гетерогенного флюида, состоящего из высококонцентрированного водно-солевого раствора в равновесии с газовой фазой, свидетельствует о его вскипании, а уменьшение концентраций солей при снижении температур могло быть вызвано их смешением с метеорными водами [22]. Об этом свидетельствует также разброс и падение значений $\delta^{18} \mathrm{O}_{\mathrm{H}_{2} \mathrm{O}}$ флюида от $+8,0$ до $-1,6 \%$, что обеспечено участием в рудообразовании низкоконцентрированных изотопнооблегченных метеорных вод [23].
Пострудные кварц-турмалиновые прожилки образовались из водно-хлоридного $\mathrm{Na}-\mathrm{K} \pm \mathrm{Mg}$ флюида с концентрациями солей $5,5 \ldots 10,4$ мас. \% NaCl-экв. при температурах $200-360{ }^{\circ} \mathrm{C}$. Сравнивая с генетически родственным рудопроявлением Улуг-Саир АМРУ, можно предположить, что ранние предрудные кварцтурмалиновые жилы на Хаак-Саире отлагались при более высоких температурах из растворов с хлоридами $\mathrm{Na}, \mathrm{K}, \mathrm{Mg}$, т. к., по нашим данным, на рудопроявлении Улуг-Саир сходные ранние предрудные турмалин-кварцевые жилы отлагались из комплексных растворов состава $\mathrm{MgCl}_{2}-\mathrm{H}_{2} \mathrm{O}+\mathrm{NaCl}-\mathrm{KCl}-\mathrm{H}_{2} \mathrm{O}$ с концентрациями солей $8 \ldots 10,6$ мас. \% NaCl-экв. при 320 $375^{\circ} \mathrm{C}$.

Развитие кварц-турмалиновых метасоматитов и жил на рудопроявлении Хаак-Саир косвенно указывает на магматогенное происхождение минералообразующего флюида [24]. В пользу этого также свидетельствует изотопный состав $\delta^{34} \mathrm{~S}_{\mathrm{H} 2 \mathrm{~S}}$ флюида I (от $+1,5$ до $+2,1 \%)$ и II $(+1,6 \ldots+2,6 \%$ рудных стадий. Кроме того, это подтверждают высокие значения солености флюида и его комплексный солевой состав с хлоридами натрия, калия и магния и гидрокарбонатами. Подобные признаки участия магматических флюидов установлены в ряде современных [25] и палеозойских золотосодержащих гидротермальных систем $[26,27]$.

По данным ICP-MS, среди анионов во флюиде преобладают гидрокарбонаты, концентрации которых существенно выше концентрации хлора. Из катионов флюид наиболее обогащен $\mathrm{Na}$ с примесями $\mathrm{Ca}, \mathrm{K}$ и $\mathrm{Mg}$, и его можно отнести к гидрокарбонатнохлоридно-натриевому типу, что не противоречит данным термометрии. Обогащение флюида рудными элементами ( $\mathrm{Sb}, \mathrm{As}, \mathrm{Cu}, \mathrm{Zn}, \mathrm{Pb}, \mathrm{Ag}, \mathrm{Ba}, \mathrm{Sr}$ ) отражает состав сульфосолей, сульфидов и сульфатов золотосодержащих минеральных ассоциаций. Присутствие в нем $\mathrm{Mo}, \mathrm{Ba}$ и $\mathrm{Sr}$ свидетельствует о генетической связи оруденения с гранитоидным магматизмом, a $\mathrm{Ni}, \mathrm{Co}$ и $\mathrm{Cr}$ обусловлены составом рудовмещающих пород.

Обобщая результаты исследования флюидных включений, установлено, что флюид имел метануглекислотно-водно-хлоридный состав. В процессе минералообразования от ранних жил к поздним наблюдается снижение доли $\mathrm{CO}_{2}$ во флюиде. На заключительных стадиях минералообразования флюид представлен водно-солевым раствором с повышенными содержаниями $\mathrm{Ba}, \mathrm{Sb}$ и As, что согласуется с минералогическими данными (наличием барита и широким развитием блеклых руд). Степень окисленности флюида $\left(\mathrm{CO}_{2} / \mathrm{CO}_{2}+\mathrm{CH}_{4}\right)$ стабильна и составляет 0,9.

Изотопный состав кислорода воды и серы флюида рудопроявления Хаак-Саир свидетельствует об участии магматогенного флюида в отложении минеральных ассоциаций ранних стадий, а на завершающих стадиях происходило смешение магматического флюида с метеорными водами.

Изотопные значения углерода флюида (от $-3,3$ до $+0,5 \%$ ) свидетельствуют о заимствовании части углерода из вмещающих терригенных пород. 
Минеральные парагенезисы ранней рудной стадии (I) свидетельствуют о том, что рудоотложение происходило при высокой фугитивности $(f)$ сульфидной серы $\lg f\left(\mathrm{~S}_{2}\right)=10^{-15,5}-10^{-6}$ (при $\left.T=200^{\circ} \mathrm{C}\right)$, поздней рудной стадии (II) - при $\lg f\left(\mathrm{~S}_{2}\right)=10^{-25}-10^{-9}, \lg f\left(\mathrm{Te}_{2}\right)=10^{-21}-10^{-9}$ и $\lg f\left(\mathrm{Se}_{2}\right)=10^{-21}-10^{-12}$ (при $T=200^{\circ} \mathrm{C}$ ) [28-30]. Уменьшение $f \mathrm{~S}_{2}$ сопровождалось ростом $f \mathrm{O}_{2}$, т. к. широкое развитие минералов ртутистого золота и селенидов $\mathrm{Au}, \mathrm{Ag}$ и $\mathrm{Hg}$ в поздних рудных жилах свидетельствует о рудообразовании при высокой $f \mathrm{O}_{2}$, предположительно, из-за смешения рудоносного флюида с высокоаэрированными метеорными водами [31].

Относительно невысокое давление (0,5-0,75 кбар), определенное для рудных стадий, косвенно указывает на малый уровень среза, а также на близость значений полученных температур гомогенизации к истинным температурам минералообразования. Эти результаты согласуются с минералого-геохимическими особенностями руд на рудопроявлении Хаак-Саир (широкое развитие минералов ртутистого золота, серебристых блеклых руд, минералов селена и теллура), свидетельствующими о близповерхностном ( 1,5-3 км) уровне отложения оруденения [1].

Таким образом, результаты изотопногеохимических и термобарогеохимических исследований хорошо согласуются с полученными ранее данными по минеральным парагенезисам и типоморфным особенностям золота [4]. Важную роль в процессе рудообразования играли температурный геохимический барьер и гетерофазное состояние флюида, связанное с его вскипанием [22], фиксирующимся, по термобарогеохимическим данным, наличием высококонцентрированного (до 37 мас. \% NaClэкв.) водно-солевого флюида в равновесии с газовой фазой. Полученные результаты указывают на сходство генезиса рудопроявления Хаак-Саир с эпитер-

\section{СПИСОК ЛИТЕРАТУРЫ}

1. Кужугет Р.В. Золото-теллуридное оруденение АлданМаадырского рудного узла (Западная Тува): минералогогеохимические особенности руд и условия их образования: автореф. дис. ... канд. геол.-минерал. наук. - Новосибирск, 2014. $-20 \mathrm{c}$.

2. Рудные формации Тувы / В.В. Зайков, В.И. Лебедев, В.Г Тюлькин, В.Н. Гречищева, К.С. Кужугет. - Новосибирск: Наука, 1981. - 201 с.

3. Кононенко Н.Б. Предварительные результаты по золотоносной Алдан-Маадырской зоне (Республика Тыва) // Геология и минеральные ресурсы Центральной Сибири: Материалы научно-практической конференции. - Красноярск: Красноярскгеолсъемка, 2011. - С. 162-166.

4. Золоторудная минерализация Хаак-Саирского золотокварцевого рудопроявления в лиственитах (Западная Тува) Р.В. Кужугет, В.В. Зайков, В.И. Лебедев, А.А. Монгуш // Геология и геофизика. - 2015. - Т. 56. - № 9. - С. 1693-1712.

5. Монгуш А.А., Кужугет Р.В., Дружкова Е.К. Особенности состава магматических пород и $\mathrm{Ar}-\mathrm{Ar}$ данные о возрасте базитовых даек Алдан-Маадырской золоторудной зоны (Западная Тува) // Металлогения древних и современных океанов2011. - Миасс: ИМин УрО РАН, 2011. - С. 262-268.

6. Реддер Э. Флюидные включения в минералах. - М.: Мир, 1978. - T. 1. $-360 \mathrm{c}$

7. Особенности эпитермального рудообразования в Кедонском палеозойском вулканоплутоническом поясе Северо-Востока России, по данным геохимических исследований $\mathrm{Au}-\mathrm{Ag}$ ору- мальными $\mathrm{Au}-\mathrm{Ag}$ месторождениями, где часто наблюдается участие метеорных вод и широкий разброс значений изотопного состава $\delta^{18} \mathrm{O}$ [32-42].

\section{Заключение}

Возраст синрудных лиственитов $(379,4 \pm 4,4$ млн лет) рудопроявления Хаак-Саир соответствует возрасту становления баянкольского комплекса позднего девона. Рудные жилы отлагались при давлении 0,5-0,75 кбар ( 1,5-2,3 км) с участием гетерофазного метан-углекислотно-водно-хлоридного $\quad(\mathrm{Na}-\mathrm{K} \pm \mathrm{Fe})$ флюида с вариациями солености 4-37 мас. \% NaClэкв. в температурном интервале $320-120{ }^{\circ} \mathrm{C}$ при изменениях $f \mathrm{O}_{2}, f \mathrm{~S}_{2}, f \mathrm{Se}_{2}$ и $f \mathrm{Te}_{2}$.

Рудоотложение протекало в условиях эволюции единого по генезису гетерофазного магматического флюида, сопровождающейся его вскипанием и/или смешением с высокоаэрированными приповерхностными водами. Предполагается, что в процессе отложения ранних рудных жил участвовал среднеконцентрированный магматический флюид, а на завершающих стадиях он смешивался с метеорными водами, становясь более низкотемпературным водно-солевым раствором с пониженной соленостью. Вовлечение в рудообразующую систему метеорных вод, обогащенных кислородом, способствовало росту $f \mathrm{O}_{2}$ с одновременным понижением $f \mathrm{~S}_{2}$, что обусловило разнообразие минеральных форм $\mathrm{Au}, \mathrm{Ag}$ и $\mathrm{Hg}$.

Авторы благодарны Е.К. Дружковой за помощьь в проведении работ. Полевые и изотопные исследования выполнены по государственному заданию ТувИКОПР СО РАН (0384-2016-0012, 0307-2021-0002), термобарогеохимические исследования выполнены в рамках государственных заданий ИГМ СО РАН (0330-2016-0002) и ИМин ЮУ ФНЦ МиГ УрО РАН.

денения / А.В. Волков, А.А. Сидоров, Н.Е. Савва, В.Ю. Прокофьев, Е.Е. Колова, К.Ю. Мурашов, М.И. Земскова // Вулканология и сейсмология. - 2016. - № 6. - С. 3-21.

8. Кряжев С.Г., Прокофьев В.Ю., Васюта Ю.В. Использование метода ICP MS при анализе рудообразующих флюидов // Вестник МГУ. Серия 4. Геология. - 2006. - № 4. - С. 30-36.

9. Ohmoto H., Rye R.O. Isotopes of sulfur and carbon // Geochemistry of hydrothermal ore deposits. - N.Y.: John Wiley and Sons, 1979. - P. 509-567.

10. Li Y., Liu J. Calculation of sulfur isotope fractionation in sulfides // Geochimica Cosmochimica Acta. - 2006. - V. 70. P. 1789-1795.

11. Ohmoto H. Stable isotope geochemistry of ore deposits // Review Mineralogy. - 1986. - V. 16. - P. 491-560.

12. Hoefs J. Stable isotope geochemistry. - Berlin; Heidelberg: Springer-Verlag, 2009. - $281 \mathrm{p}$.

13. Мелекесцева И.Ю., Каварая Х., Мацубая О. Источник флюида при формировании золото-кварцевых жил Хаак-Саирского и Улуг-Саирского месторождений (Западная Тува) по данным изотопного состава кислорода // Металлогения древних и современных океанов-2012. - Миасс: ИМин УрО РАН, 2012. C. $210-213$.

14. Oxygen isotope fractionation in the quartz-water-salt system / L-G. Zhang, J.-X. Liu, H.B. Zhou, Z.-S. Chen // Economic Geology. - 1989. - V. 89. - P. 1643-1650.

15. Zheng Y.F. Oxygen isotope fractionation in carbonate and sulfate minerals // Geochemical Journal. - 1999. - V. 33. - P. 109-126.

16. Bottinga $Y$. Calculated fractionation factors for carbon and hydrogen isotope exchange in the system calcite-carbon dioxide- 
graphite-methane-hydrogen-water vapor // Geochimica et Cosmochimica Acta. - 1969. - V. 33. - P. 49-64.

17. Sheppard S.M.F., Schwartz H.P. Fractionation of carbon and oxygen isotopes and magnesium between coexisting metamorphic calcite and dolomite // Contributions to Mineralogy and Petrology. - 1970. - V. 26. - P. 161-198.

18. Jia Y., Kerrich R. Giant quartz vein systems in accretionary orogenic belts: the evidence for a metamorphic fuid origin from $\delta 15 \mathrm{~N}$ and $\delta 13 \mathrm{C}$ studies // Earth and Planetary Science Letters. 2000. - V. 184. - P. 211-224.

19. Лебедев В.И. Кобальтовые месторождения Тувы и сопредельных регионов Центральной Азии. - Барнаул: Изд-во «Новый формат», 2018. - $203 \mathrm{c}$

20. Борисенко А.С. Физико-химические условия формирования лиственитов Алтае-Саянской складчатой области (по данным изучения газово-жидких включений // Геология и генезис рудных месторождений Юга Сибири. - Новосибирск: Наука, 1977. - C. $144-157$.

21. Исследование флюидных включений в минералах Олимпиандинского $\mathrm{Au}-(\mathrm{Sb}-\mathrm{W})$ месторождения (Енисейский кряж) / В.Ю. Прокофьев, З.Б. Афанасьева, Г.Ф. Иванова, М.К. Буарон, Х. Мариньяк // Геохимия. - 1994. - Т. 7. - С. 1012-1029.

22. Wilkinson J.J. Fluid inclusions in hydrothermal ore deposits // Lithos. - 2001. - V. 55. - P. 229-272.

23. Состав магматогенных флюидов, факторы их геохимической специализации и металлоносности / А.С. Борисенко, А.А. Боровиков, Л.М. Житова, Г.Г. Павлова // Геология и геофизика. - 2006. - Т. 47 (12). - С. 1308-1325.

24. Бор и борные кислоты в эндогенных рудообразующих флюидах / В.Ю. Прокофьев, И.С. Перетяжко, С.З. Смирнов, Н.Н. Акинфиев, Ф.Г. Рейф, Ю.М. Ишков, Б.Р. Тагиров, Е.О. Грознова, М.В. Воронин. - М.: Пасьва, 2003. - 192 с.

25. Gold-rich polymetallic sulfides from the Lau back arc and implications for the geochemistry of gold in sea-floor hydrothermal systems of the Southwest Pacific / P.M. Herzig, M.D. Hannington, Y. Fouquet, U. Stackelberg, S. Petersen // Economic Geology. - 1993. - V. 88. - № 8. - P. 2182-2209.

26. Бакшеев И.А., Прокофьев В.Ю., Устинов В.И. Условия формирования жильного кварца Березовского золоторудного поля, Средний Урал, по данным изучения флюидных включений и изотопным данным // Материалы Уральской летней минералогической школы-1998. - Екатеринбург: УГГГА, 1998. C. 41-49.

27. Yang K., Scott S.D. Magmatic fluids as a source of metals in seafloor hydrothermal systems // Geophysical Monograph Series. - 2006. - № 166. - P. 163-184.

28. Barton P.B., Skinner B.J. Sulfide mineral stabilities // Geochemistry of Hydrothermal Ore Deposits / Ed. by H.L. Barnes. New York: John Willey and Sons, 1979. - P. 278-403.

29. Afifi A.M., Kelly W.C., Essene E.J. Phase relations among tellurides, sulfides, and oxides: I. Thermochemical data and calculated equilibria // Economic Geology. - 1988. - V. 83. P. 377-394.

30. Физико-химические условия образования минеральных парагенезисов золота и серебра на месторождении Валунистое. (Чукотка) / Т.В. Журавкова, Г.А. Пальянова, Ю.А. Калинин, Н.А. Горячев, В.Ю. Зинина, Л.М. Житова // Геология и геофизика. - 2019. - Т. 60. - № 11. - С. 1565-1576.
31. Бортников Н.С., Генкин А.Д., Коваленкер В.А. Минералогогеохимические показатели условий гидротермального рудообразования // Эндогенные рудные районы и месторождения. М.: Наука, 1987. - С. 40-59.

32. Berger B.R., Henley R.W. Advances in understanding of epithermal gold-silver deposits with special reference to the Western United States // Economic Geology. - 1989. - V. 84. P. 405-423.

33. Hedenquist J.W., Brown P.R., Allis R.G. Epithermal gold mineralization // Applied Geology Association. - Wairakei: New Zealand, 1998. - $162 \mathrm{p}$

34. Physicochemical models of formation of gold-silver ore mineralization at the Rogovik deposit (Northeastern Russia) / T.V. Zhuravkova, G.A. Palyanova, K.V. Chudnenko, R.G. Kravtsova, I.R. Prokopyev, A.S. Makshakov, A.S. Borisenko // Ore Geology Reviews. - 2017. - V. 91. - P. 1-20.

35. Условия формирования $\mathrm{Au}-\mathrm{Ag}$ эпитермальной минерализации Кайенмываамского рудного поля (Центральная Чукотка) / В.Ю. Прокофьев, А.В. Волков, Ю.Н. Николаев, И.А. Калько, Е.А. Власов, А.А. Сидоров // Руды и металы. - 2019. - № 1. C. $52-57$.

36. Contrasting fluids in the Svetlinsk gold-telluride hydrothermal system, South Urals / O. Vikent'eva, V. Prokofiev, E. Groznova, I. Vikentyev, N. Bortnikov, A. Borovikov, S. Kryazhev, M. Pritchin // Minerals. - 2020. - V. 1. - P. 1-27.

37. Таежное эпитермальное жильное месторождение серебряных руд (Сихотэ-Алинь): региональная позиция, условия образования, геохимия и минеральный состав / В.В. Раткин, Л.Ф. Симаненко, В.А. Пахомова, О.А. Елисеева // Тихоокеанская геология. - 2021. - Т. 40. - № 2. -С. 21-38.

38. Mineral chemistry, fluid inclusion and stable isotope studies of the Suyoc epithermal veins: Insights to $\mathrm{Au}-\mathrm{Cu}$ mineralization in southern Mankayan Mineral District, Philippines / O.B. Soberano, J.A.S. Gabo-Rati, K.L. Queaño, C.B. Dimalanta, Jr.G.P. Yumul, E.S. Andal, K. Yonezu and A.J. Boyce // Ore Geology Reviews. 2021. - V. 131. - P. 104035

39. A review of intermediate sulfidation epithermal deposits and subclassification / L. Wang, K.-Z. Qin, G.-X. Song, G.-M. Li // Ore Geology Reviews. - 2019. - V. 10. - P. 434-456.

40. Гусев А.И., Табакаева Е.М. Магматизм и эпитермальное AgАu оруденение Красноярского рудного поля Горного Алтая // Известия Томского политехнического университета. Инжиниринг георесурсов. - 2019. - Т. 330. - № 1. - С. 26-38.

41. Условия формирования $\mathrm{Au}-\mathrm{Ag}$ эпитермальной минерализации Амгуэмо-Канчаланского вулканического поля (Восточная Чукотка) / А.В. Волков, В.Ю. Прокофьев, А.А. Сидоров, С.Ф. Винокуров, А.А. Елманов, К.Ю. Мурашов, Н.В. Сидорова // Вулканология и сейсмология. - 2019. - № 5. - С. 68-80.

42. Эпитермальное $\mathrm{Au}-\mathrm{Ag}$ месторождение Валунистое (Восточная Чукотка, Россия): геологическое строение, минералогогеохимические особенности и условия рудообразования / А.В. Волков, В.Ю. Прокофьев, С.Ф. Винокуров, О.В. Андреева, Г.Д. Киселева, А.Л. Галямов, К.Ю. Мурашов, Н.В. Сидорова // Геология рудных месторождений. - 2020. - Т. 62. № 2. - C. 107-133.

Поступила 28.10.2021 г.

\section{Информация об авторах}

Kужж⿻ет P.B., кандидат геолого-минералогических наук, директор Тувинского института комплексного освоения природных ресурсов СО РАН.

Анкушева Н.Н., кандидат геолого-минералогических наук, научный сотрудник лаборатории минералогии рудогенеза Института минералогии ЮУ ФНЦ МиГ УрО РАН.

Кадыр-оол Ч.О., инженер лаборатории геодинамики, магматизма и рудообразования Тувинского института комплексного освоения природных ресурсов СО РАН.

$\boldsymbol{P e д u н а ~ A . A . , ~ м л а д ш и и ̆ ~ н а у ч н ы и ̆ ~ с о т р у д н и к ~ л а б о р а т о р и и ~ р у д о н о с н о с т и ~ щ е л о ч н о г о ~ м а г м а т и з м а ~ И н с т и т у т а ~ г е о - ~}$ логии и минералогии им. В.С. Соболева СО РАН.

Прокопьев И.Р., кандидат геолого-минералогических наук, научный сотрудник лаборатории рудоносности щелочного магматизма Института геологии и минералогии им. В.С. Соболева СО РАН.

Пономарчук A.B., младший научный сотрудник лаборатории изотопно_аналитической геохимии Института геологии и минералогии им. В.С. Соболева СО РАН. 
UDC 553.2: 549.283 (571.52)

\section{KHAAK-SAIR GOLD-SULFIDE-QUARTZ ORE OCCURRENCE (WESTERN TUVA): DATING, PT PARAMETERS, FLUID COMPOSITION, AND ISOTOPES OF S, O AND C}

Renat V. Kuzhuget ${ }^{1}$, rkuzhuget@mail.ru

Natalia N. Ankusheva², ankusheva@mail.ru

Chayana 0. Kadyr-ool ${ }^{1}$, kadyrool91@mail.ru

\author{
Anna A. Redina ${ }^{3}$, \\ anna-red@outlook.com
}

llya R. Prokopyev3, prokopev_ilya@mail.ru

Anton V. Ponomarchuk ${ }^{3}$, antponomar@gmail.com

1 Tuvinian Institute for Exploration of Natural Resources SB RAS,

117 a, Internatsionalnaya street, Kyzyl, 667007, Russia.

2 Institute of Mineralogy SU FRC MG UB RAS,

1, Ilmensky Reserve, Miass, 456317, Russia.

3 VS Sobolev Institute of Geology and Mineralogy SB RAS,

3, Academician Koptyug avenue, Novosibirsk, 630090, Russia.

The relevance of the research is caused by the need to determine the age and fluid regime of formation of Khaak-Sair gold-sulfide-quartz ore occurrence in listwanites, characterized by a peculiar ore mineral composition, expressed in the presence of mercurial gold, selenides (fichesserite, naumannite, timannite, claustallite) and tellurides (hessite, Te-bismuthite and coloradoite).

The research is aimed to date and examine PT ore-bearing fluid parameters and geochemical peculiarities, and the fluid sources of Khaak-Sair gold-sulfide-quartz ore occurrence in Western Tuva.

Methods. ${ }^{40} \mathrm{Ar} /{ }^{39} \mathrm{Ar}$ dating was carried out by the method of step heating. The optical studies of ores were performed on Olympus BX41 and P-213M optical microscopes. The mineral composition was detected using MIRA 3 LMU scanning electron microscope with EDU of Oxford Instruments Nanoanalysis Ltd. The temperatures, salt composition, salinities and fluid pressures were obtained from individual fluid inclusions using Linkam TMS-600 stage equipped with Olympus BX 51 optical microscope; the volatile composition of fluid inclusions was examined on Ramanor U-1000 spectrometer with the Horiba DU420E-OE-323 detector, Millennia Pro laser (Spectra-Physics); the bulk volatile composition of the fluid was determined on the Agilent 6890 gas chromatograph, the anions in the water extraction was estimated on the CVET-3000 ion chromatograph, the cation and trace elements were detected by ICP MS (Elan-6100); the sulfur isotope ratios in galena were calculated on Finnigan MAT Delta gas mass-spectrometer in double-entry mode (analysts V.N. Reutsky and M.N. Kolbasova, IGM SB RAS); $\delta^{18} \mathrm{C}$ and $\delta^{18} \mathrm{O}$ isotopic ratios in quartz and carbonates were examined on Stable Isotope Ratio Mass Spectrometer Finnigan $^{\mathrm{TM}}$ MAT 253 with Finnigan GasBench II sampler and IAEA standards: NBS-18 and NBS-19 (analyst M.N. Pyryaev, IGM SB RAS) and Isoprime with AQS (Akita Quartz Standard, analysts H. Kavarai, O. Matsubaya, University of Akita), respectively.

Results. The ${ }^{40} \mathrm{Ar} /{ }^{\beta 9} \mathrm{Ar}$ dating of synore listwanites is shown $379,4 \pm 4,4$ million years that corresponds to the Late Devonian. We identified that the ore hosted listwanites were formed due to aqueous Na-K-chloride fluid with salinity of 3,4-6,5 wt. \% NaCl eqv and temperatures at least $325-200{ }^{\circ} \mathrm{C}$. Gold-sulfide-quartz veins were formed at P 0,5-0,75 kbar $(\sim 1,5-2,3 \mathrm{~km})$ due to $\mathrm{CO}_{2}$-water chloride ( $\left.\mathrm{Na}-\mathrm{K} \pm \mathrm{Fe}\right)$ fluid containing $\mathrm{CH}_{4}$ with salinity ranged between 4,5 and $37,4 \mathrm{wt} . \% \mathrm{NaCl}$ eqv. and temperatures from 320 up to $120{ }^{\circ} \mathrm{C}$ (I ore substage $310-200^{\circ} \mathrm{C}$ and II ore substage $-320-120^{\circ} \mathrm{C}$ ), and with $\mathrm{fO}_{2}, \mathrm{fS}_{2}, \mathrm{fSe}_{2}$ and $\mathrm{fTe}_{2}$ variations that have contributed to the diversity of $\mathrm{Au}, \mathrm{Ag}$ and $\mathrm{Hg}$ mineral forms. The values of $\delta^{34} \mathrm{~S}$ from galena vary from $-0,6$ to $-0,4 \%$, and the calculated values of $\delta^{34} \mathrm{~S}_{\mathrm{H} 2 \mathrm{~S}}$ of I ore substage fluid vary from $+1,5$ to $+2,1 \%$ o (for $T=280-210^{\circ} \mathrm{C}$ ), and II ore substage fluid $-+1,6 \ldots+2,6 \%$ (for $T=290-190{ }^{\circ} \mathrm{C}$ ), which indicates the magmatic origin of sulfur. Values of $\delta^{18} \mathrm{O}$ in quartz from ore veins vary from 17,0 to $17,4 \%$, dolomite $-+17,4 \ldots+17,8 \%$, calcite $-+16,5 \%$, and calculated values of $\delta^{18} \mathrm{OH}$ 2S of I ore substage fluid vary from $+8,1$ to $+5,7 \%$ (for $T=250-210{ }^{\circ} \mathrm{C}$ ), and II ore substage $-+6,7 \%$. ...-2,2\%o (for $T=230-120^{\circ} \mathrm{C}$ ) suggested that in the early stages of the ore-forming process fluid was of magmatic origin, and in later stages it was mixed with meteoric waters. The values of $\delta^{13} \mathrm{C}$ in dolomite of I ore substage vary from $-0,4$ to $-0,7 \%$; calcite of II ore substage - -0,3\%, and the calculated values of $\delta^{13} \mathrm{C}$ in the fluid vary from $-1,2$ to $+0,1 \%$ (for $T=250-210^{\circ} \mathrm{C}$ ) and from $-3,3$ to $+0,5 \%$ (for $\mathrm{T}=230-120^{\circ} \mathrm{C}$ ), respectively. This presupposes carbon inflow from granitoid magmas and/or its borrowing from host rocks. The composition of the fluid was transformed from early to late substages from carbon dioxide to water chloride with a decrease in chloride amounts of alkali and alkaliearth metals (from 37,4 to 4 wt. \% $\mathrm{NaCl}$ eqv).

\section{Key words:}

Native gold, fluid inclusions, quartz, dating, stable isotopes, gold deposits, Tuva.

The authors are grateful to Evgenia K. Druzhkova for research assistance. Mineralogical, geochemical and isotopic researches were supported by the State Contract of TuvIEN SB RAS (0384-2016-0012, 0307-2021-0002), fluid inclusion study was supported by State Contract of the Institute of Geology and Mineralogy SB RAS (0330-2016-0002) and Institute of Mineralogy SU FRC MG $U B R A S$. 


\section{REFERENCES}

1. Kuzhuget R.V. Zoloto-telluridnoe orudenenie Aldan-Maadyrskogo rudnogo uzla (Zapadnaya Tuva): mineralogo-geokhimicheskie osobennosti rud $i$ usloviya ikh obrazovaniya. Avtoreferat Dis. Kand. nauk [Gold-telluride mineralization of the Aldan-Maadyr ore cluster (Western Tuva): mineralogical and geochemical peculiarities of ores and their formation conditions. Cand. Diss. Abstract]. Novosibirsk, 2014. 20 p.

2. Zaykov V.V., Lebedev V.I., Tyulkin V.G., Grechishcheva V.N. Kuzhuget K.S. Rudnye formatsii Tuvy [Ore formations of Tuva]. Novosibirsk, Nauka Publ., 1981. 201 p.

3. Kononenko N.B. Predvaritelnye rezultaty po zolotonosnoy AldanMaadyrskoy zone (Respublika Tyva) [Preliminary results of the Aldan-Maadyr gold-bearing zone (Republic of Tyva)]. Geologiya i mineralnye resursy Tsentralnoy Sibiri: Materialy nauchnoprakticheskoy konferentsii [Geology and Mineral Resources of Central Siberia. Proceedings of the Scientific and Practical Conference]. Krasnoyarsk, Krasnoyarskgeolsemka Publ., 2011. pp. $162-166$.

4. Kuzhuget R.V., Zaikov V.V., Lebedeva V.I., Mongush A.A. Gold mineralization of the Khaak-Sair gold-quartz ore occurrence in listwanites (western Tuva). Russian Geology and Geophysics, 2015, vol. 56, pp. 1332-1348.

5. Mongush A.A., Kuzhuget R.V. Druzhkova E.K. Osobennost sostava magmaticheskikh porod i Ar-Ar dannye o vozraste bazitovykh daek Aldan-Maadyrskoy zolotorudnoy zony (Zapadnaya Tuva) [Composition of igneous rocks and Ar-Ar data on the age of basic dikes of the Aldan-Maadyr gold ore zone (Western Tuva)]. Metallogeniya drevnikh i sovremennykh okeanov-2011 [The metallogeny of ancient and modern oceans]. Miass, IMin UB RAS Publ., 2011. pp. 262-268.

6. Roedder E. Flyuidnye vklyucheniya v mineralakh [Fluid inclusions in minerals]. Moscow, Mir Publ., 1987. 360 p.

7. Volkov A.V., Sidorov A.A., Savva N.E., Prokofev V.Yu., Kolova E.E., Murashov K.Yu., Zemskova M.I. Epithermal mineralization in the Kedon Paleozoic volcano-plutonic belt, Northeast Russia: Geochemical studies of $\mathrm{Au}-\mathrm{Ag}$ mineralization. Journal of Volcanology and Seismology, 2019, vol. 11, no. 1, pp. 1-19.

8. Kryazhev S.G., Prokofiev V.Yu., Vasyuta Yu.V. Ispolzovanie metoda ICP MS pri analize rudoobrazuyushchikh flyuidov [The usage of ICP MS for ore-forming fluid analysis]. Vestnik $M G U$, 2006, no. 4, pp. 30-36.

9. Ohmoto H., Rye R.O. Isotopes of sulfur and carbon. Geochemistry of hydrothermal ore deposits. N.Y., John Wiley and Sons, 1979. pp. 509-567.

10. Li Y., Liu J. Calculation of sulfur isotope fractionation in sulfides. Geochimica Cosmochimica Acta, 2006, vol. 70, pp. 1789-1795.

11. Ohmoto H. Stable isotope geochemistry of ore deposits. Review Mineralogy, 1986, vol. 16, pp. 491-560.

12. Hoefs J. Stable isotope geochemistry. Berlin, Heidelberg, Springer-Verlag, 2009. $281 \mathrm{p}$

13. Melekestseva I.Yu., Kavaraya H., Matsubaya O. Istochnik flyuida pri formirovanii zoloto-kvartsevykh zhil Khaak-Sairskogo i UlugSairskogo mestorozhdeniy (Zapadnaya Tuva) po dannym izotopnogo sostava kisloroda [The fluid source at the gold-quartz veins formation of Khaak-Sair and Ulug-Sair deposits (Western Tuva)] Metallogeniya drevnikh i sovremennykh okeanov-2012 [The metallogeny of ancient and modern oceans]. Miass, IMin UB RAS Publ. 2012. pp. 210-213.

14. Zhang L-G., Liu J.-X., Zhou H.B., Chen Z.-S. Oxygen isotope fractionation in the quartz-water-salt system. Economic Geology, 1989, vol. 89, pp. 1643-1650.

15. Zheng Y.F. Oxygen isotope fractionation in carbonate and sulfate minerals. Geochemical Journal, 1999, vol. 33, pp. 109-126.

16. Bottinga Y. Calculated fractionation factors for carbon and hydrogen isotope exchange in the system calcite-carbon dioxidegraphite-methane-hydrogen-water vapor. Geochimica et Cosmochimica Acta, 1969, vol. 33, pp. 49-64.

17. Sheppard S.M.F., Schwartz H.P. Fractionation of carbon and oxygen isotopes and magnesium between coexisting metamorphic calcite and dolomite. Contributions to Mineralogy and Petrology, 1970, vol. 26, pp. 161-198.

18. Jia Y., Kerrich R. Giant quartz vein systems in accretionary orogenic belts: the evidence for a metamorphic fuid origin from $\delta^{15} \mathrm{~N}$ and $\delta^{13} \mathrm{C}$ studies. Earth and Planetary Science Letters, 2000. vol. 184, pp. 211-224

19. Lebedev V. I. Kobaltovye mestorozhdeniya Tuvy $i$ sopredelnykh regionov Tsentralnoy Azii [Cobalt deposits of Tuva and adjacent regions of Central Asia]. Barnaul, New format Publ., 2018. pp. 173-174.

20. Borisenko A.S. Fiziko-khimicheskie usloviya formirovaniya listvenitov Altae-Sayanskoy skladchatoy oblasti (po dannym izucheniya gazovo-zhidkikh vklyucheniy [Physicochemical conditions for the formation of listvenites of the Altai-Sayan folded area (according to the study of gas-liquid inclusions]. Geologiva $i$ genezis rudnykh mestorozhdeniy Yuga Sibiri [Geology and genesis of ore deposits in the South of Siberia]. Novosibirsk, Nauka Publ., 1977. pp. 144-157.

21. Prokofev V.Yu., Afanaseva Z.B., Ivanova G.F., Buaron M.K., Marinyak H. Issledovanie flyuidnykh vklyucheniy v mineralakh Olimpiandinskogo Au-(Sb-W) mestorozhdeniya (Eniseyskiy kryazh) [Fluid inclusion study of minerals from Olympiandinsky Au-(Sb-W) deposit (the Yenisey Ridge)]. Russian Geochemistry, 1994, vol. 7, pp. 1012-1029.

22. Wilkinson J.J. Fluid inclusions in hydrothermal ore deposits. $\mathrm{Li}$ thos, 2001, vol. 55, pp. 229-272.

23. Borisenko A.S., Borovikov A.A., Zhitova L.M., Pavlova G.G. Composition of magmatogene fluids and factors determining their geochemistry and metal contents. Russian Geology and Geophysics, 2006, vol. 47, no. 12, pp. 1308-1325. In Rus.

24. Prokofev V.Yu., Peretyazhko I.S., Smirnov S.Z., Tagirov B.R., Groznova E.O., Samsonova E.A. Bor $i$ bornye kisloty v endogennykh rudoobrazuyushchikh flyuidakh [Boron and boric acid in endogenous ore-forming processes]. Moscow, PASVA Publ., 2003. $192 \mathrm{p}$

25. Herzig P.M., Hannington M.D., Fouquet Y., Stackelberg U., Petersen S. Gold-rich polymetallic sulfides from the Lau back arc and implications for the geochemistry of gold in sea-floor hydrothermal systems of the Southwest Pacific. Economic Geology, 1993, vol. 88, no. 8, pp. 2182-2209.

26. Baksheev I.A., Prokofev V.Yu., Ustinov V.I. Usloviya formirovaniya zhilnogo kvartsa Berezovskogo zolotorudnogo polya, Sredniy Ural, po dannym izucheniya flyuidnykh vklyucheniy i izotopnym dannym [Conditions of formation of vein quartz of the Berezovsky gold ore field, the Middle Urals: fluid inclusions and isotope data]. Materialy Uralskoy letney mineralogicheskoy shkoly-1998 [Materials of the Ural Summer Mineralogical School1998]. Ekaterinburg, UGGGA Publ., 1998. pp. 41-49.

27. Yang K., Scott S.D. Magmatic fluids as a source of metals in seafloor hydrothermal systems. Geophysical Monograph Series, 2006 , no. 166, pp. 163-184.

28. Barton P.B., Skinner B.J. Sulfide mineral stabilities. Geochemistry of Hydrothermal Ore Deposits. Ed. by H.L. Barnes. New York, John Willey and Sons, 1979. pp. 278-403.

29. Afifi A.M., Kelly W.C., Essene E.J. Phase relations among tellurides, sulfides, and oxides: I. Thermochemical data and calculated equilibria; II. Applications to telluride-bearing ore deposits. Economic Geology, 1988, vol. 83, pp. 377-394.

30. Zhuravkova T.V., Palyanova G.A., Kalinin Y.A., Goryachev N.A., Zinina V.Y., Zhitova L.M. Physicochemical conditions of formation of gold and silver parageneses at the valunistoe deposit (Chukchi peninsula). Russian Geology and Geophysics, 2019, vol. 60 (11), pp. 1247-1256.

31. Bortnikov N.S., Genkin A.D., Kovalenker V.A. Mineralogogeokhimicheskie pokazateli usloviy gidrotermalnogo rudoobrazovaniya [Mineralogical and geochemical indicators of hydrothermal ore formation conditions]. Endogennye rudnye rayony $i$ mestorozhdeniya [Endogenous ore regions and deposits]. Moscow, Nauka Publ., 1987. pp. 40-59.

32. Berger B.R., Henley R.W. Advances in understanding of epithermal gold-silver deposits with special reference to the Western United States. Economic Geology, 1989, vol. 84, pp. 405-423.

33. Hedenquist J.W., Brown P.R., Allis R.G. Epithermal gold mineralization. Applied Geology Association. Wairakei, New Zealand, 1998. $162 \mathrm{p}$.

34. Zhuravkova T.V., Palyanova G.A., Chudnenko K.V., Kravtsova R.G., Prokopyev I.R., Makshakov A.S., Borisenko A.S. Physicochemical models of formation of gold-silver ore mineralization at the 
Rogovik deposit (Northeastern Russia). Ore Geology Reviews, 2017, vol. 91, pp. 1-20.

35. Prokofyev V.Yu., Volkov A.V., Nikolayev Yu.N., Kalko I.A., Vlasov E.A., Sidorov A.A. Au-Ag epithermal mineralization formation conditions at Kaienmyvaamskoe ore field, Central Chukotka. Rudy i metally, 2019, no. 1, pp. 52-57. In Rus.

36. Vikenteva O., Prokofiev V., Groznova E., Vikentyev I., Bortnikov N., Borovikov A., Kryazhev S., Pritchin M. Contrasting fluids in the Svetlinsk gold-telluride hydrothermal system, South Urals. Minerals, 2020, vol. 1, pp. 1-27.

37. Ratkin V.V., Simanenko L.F., Pakhomova V.A., Eliseeva O.A Taezhny epithermal deposit of silver ore (Sikhote-Alin): regional position, formation conditions, geochemistry and mineral composition. Russian Journal of Pacific Geology, 2021, vol. 40, no. 2, pp. 21-38. In Rus.

38. Soberano O.B., Gabo-Ratio J.A.S., Queaño K.L., Dimalanta C.B. Yumul Jr., G.P., Andal E.S., Yonezu K., Boyce A.J. Mineral chemistry, fluid inclusion and stable isotope studies of the Suyoc epithermal veins: insights to $\mathrm{Au}-\mathrm{Cu}$ mineralization in southern Mankayan Mineral District, Philippines. Ore Geology Reviews, 2021, vol. 131, pp. 104035.
39. Wang L., Qin K.-Z., Song G.-X., Li G.-M. A review of intermediate sulfidation epithermal deposits and subclassification. Ore Geology Reviews, 2019. vol. 107, pp. 434-456.

40. Gusev A.I., Tabakaeva E.M. Magmatizm and epithermal Ag-Au ore mineralization of Krasnoyarsk gold ore field of Gorny Altai. Bulletin of the Tomsk Polytechnic University. Geo Assets Engineering, 2019, vol. 330, no. 1, pp. 26-38. In Rus.

41. Volkov A.V., Prokofiev V.Y., Sidorov A.A., Vinokurov S.F., Elmanov A.A., Murashov K.Yu, Sidorova N.V. The conditions of formation of $\mathrm{Au}-\mathrm{Ag}$ epithermal mineralization of the AmguemoKanchalan volcanic field (Eastern Chukotka). Journal of Volcanology and Seismology, 2019, vol. 13, no. 5, pp. 335-347. In Rus.

42. Volkov A.V., Prokofiev V.Y., Vinokurov S.F., Andreeva O.V., Kiseleva G.D., Galyamov A.L., Murashov K.Yu, Sidorova N.V. Valunistoe Epithermal Au-Ag Deposit (East Chukotka, Russia): geological structure, mineralogical-geochemical peculiarities and mineralization conditions. Geology of Ore Deposits, 2020, vol. 62, no. 2 , pp. $97-121$

Received: 28 October 2021.

\section{Information about the authors}

Renat V. Kuzhuget, Cand. Sc., director, Tuvinian Institute for Exploration of Natural Resources SB RAS.

Natalia N. Ankusheva, Cand. Sc., scientist, Institute of Mineralogy SU FRC MG UB RAS.

Chayana O. Kadyr-ool, engineer, Tuvinian Institute for Exploration of Natural Resources SB RAS.

Anna A. Redina, junior researcher, V.S. Sobolev Institute of Geology and Mineralogy SB RAS.

Ilya R. Prokopyev, Cand. Sc., scientist, V.S. Sobolev Institute of Geology and Mineralogy SB RAS.

Anton V. Ponomarchuk, graduate student, junior researcher, V.S. Sobolev Institute of Geology and Mineralogy SB RAS. 